\title{
Luck as a Double-Edged Sword: Personnel and Performance Changes after Lucky Outcomes in the National Football League
}

\author{
Kyle Siler \\ Utrecht University \\ ksiler <at> gmail [dot] com
}

February 20, 2019

Preliminary Draft: Comments Welcome! 


\begin{abstract}
Luck is an omnipresent factor which influences experiences and outcomes for individuals and organizations. This article analyzes how lucky and unlucky outcomes influence future organizational learning, decision-making and performance. Team statistics and outcomes are analyzed over 769 National Football League seasons for 32 franchises from 1990-2015. Four specific sources of luck are identified and measured: 1) divergence of win outcomes from actual team quality; 2) difficulty of opposition; 3) fumble recovery rates and 4) player injuries. Teams and players have little or no influence over these lucky factors, which nevertheless influence game outcomes, and by extension, the careers of players and coaches. Luck alters game outcomes and in turn significantly influences the retention or firing of coaches and players, which shapes their career incentives and decision-making. In addition to negatively affecting future performance via distorted learning, luck can also generate perverse incentives; in this case, encouraging risk aversion and scapegoating. Mistaking noise for signal - and conflating luck with skill - is conducive to poorer future decisions and outcomes. Paradoxically, luck can provide a means of skill-based advantage for savvy decision-makers, who learn more effectively from noisy feedback than others who are misled.
\end{abstract}


"You never know what worse luck your bad luck has saved you from." - Cormac McCarthy

\section{INTRODUCTION}

Feedback is often noisy and random. Good choices can yield adverse outcomes, while bad decisions sometimes achieve desired goals. People and organizations often must cope with situations where outcomes do not accurately reflect the merit of their performance and choices. Learning optimal strategies and best practices is particularly challenging in contexts with luck-influenced feedback, when outcomes are influenced by forces outside of the application of skillful strategies and actions. People often develop false beliefs in complex contexts where developing precise knowledge of causal relationships is difficult or impossible (Levitt and March 1988, Taleb 2001). March (2010) posited that since knowledge is limited and biased in a complex world, matching appropriate beliefs and action to experience is difficult and prone to misdirection. This article develops the notion that chance outcomes influence perceptions of luck and skill, while also affecting future performance via distorted feedback. Paradoxically, luck can generate additional sources of skill, as savvy learners learn more effectively from noisy feedback and are adept at making attributions of responsibility based on appropriate demarcations of noise and signal.

The behavioral theory of the firm is predicated on the notion that organizations learn from - and respond differently to - experiences of success and failure, which influences future decisions, behaviors and performance outcomes (Cyert and March 1963, Gavetti et al. 2012). Perceptions of success and failure can be shaped by organizational aspirations (March and Shapira 1992, Greve 1998), as well as vicarious learning from the experiences of others (Manz and Sims 1981, Denrell 2003, KC et al. 2013). Substantial research has been conducted on how individuals and organizations respond to positive and negative outcomes from both learning (March 2010, Argote 2013) and decision-making (Kahneman and Tversky 1979, Baron and Hershey 1988) perspectives (Denrell et al. 2015, Liu and de Rond 2016). This raises the 
question of how individuals and organizations cope with and learn from unfair, uncertain and/or inaccurate feedback.

Luck has implications for learning, decision-making, distributive justice and performance in organizations. Outcomes, rewards and performance quality are not always perfectly correlated. Often, there are discrepancies between input quality and outcomes. Perfect meritocracies in organizations and markets are rare. In turn, recognizing the challenge of learning from distortionary feedback is important for organizations to optimize learning and decision-making. The disjuncture between performance and rewards also raises the broader macro-level issue of how different mixtures of skill and luck in competition affect hierarchies and incentives in markets and organizations. To examine how distortionary feedback influences organizational learning and decision-making, the impact of lucky and unlucky outcomes on subsequent performance is observed for NFL (National Football League) franchises. Specifically, the effects of lucky and unlucky seasons on leadership and personnel changes - as well as performance outcomes - are analyzed.

\section{PRIOR LITERATURE}

Information distortions are a pervasive source of performance degradation in organizations (Carley and Lin 1997). As individuals and organizations strive for desired outcomes in competitive contexts, strategies and behaviors are influenced by successes and failures (Cyert and March 1963, Argote 2013). Successful outcomes positively reinforce strategies and personnel, while failures or lukewarm successes encourage change (March 1991). Generally, organizational knowledge and performance improve with experience (Argote et al. 1990, Baum and Dahlin 2007). However, outcomes may provide ambiguous and/or inaccurate feedback, which renders learning best practices a significant challenge. Experience can be a good or bad teacher, due to uncertain and/or complex signals (March 2010, Argote and Miron-Spektor 2011). Competitors learn and adapt based on feedback, but do not necessarily always improve in optimal or even positive - ways (Huber 1991). Emotionally charged and misleading feedback are conducive to incorrect learning. Both good and bad luck pose challenges for decision-makers and are threats to future 
performance. Success can encourage overconfidence, complacency, excessive risk-taking and poorer future performance (Feather 1969, Gilovich and Douglas 1986, Audia et al. 2000, Gervais and Odean 2001, Gino and Pisano 2011, Grossman and Owens 2012). Unmerited or illusory successes exacerbate these pitfalls of organizational learning. Further, learning processes are often biased due to the tendency of individuals to only sample and replicate experiences with successful outcomes (Denrell 2003). In contrast, unlucky failures can distort learning, deflate confidence and discourage people from taking worthwhile risks in the future (Denrell and March 2001, Shiv et al. 2005).

Learning - whether experiential or vicarious - can potentially have positive or negative influences on the quality of future performance and decision-making (Greve 2003). Organizations often learn incorrect lessons and adopt inferior strategies due to noisy or misleading feedback (Kahneman et al. 2017). In contexts where luck plays a substantial role in determining success, post hoc results-based evaluations ascribe excessive skill and credit to merely lucky outcomes (Pluchino et al. 2018). When organizations experience favorable outcomes with inferior procedures, this encourages further development of suboptimal strategies. Levitt and March (1988) dubbed processes where favorable performances with inferior strategies compel people or organizations to persist with such strategies competency traps. These 'traps' explain in part why many decision-makers do not learn or improve with experience. In some cases, decision-makers can become less competent with learning and experience, especially when they learn from inaccurate feedback. Variance and uncertainty obfuscate causal relationships between actions and outcomes. Levitt and March (1988) identified superstitious learning as a related decision-making pitfall, where decisionmakers learn to misplace causal links between actions and outcomes, based on compelling but anomalous or random experiences.

People often mistake luck for skill (Langer 1975, Baron and Hershey 1988). Such misperceptions are particularly prevalent in situations with inconsistent feedback and with skill-luck hybrid games (Larkey et al. 1997), which involve the challenge of disentangling luck from skill. People perceive and react to successes and failures differently. Famously, Kahneman and Tversky (1979) found that perceived gains are 
conducive to subsequent risk aversion, while perceived losses trigger risk-seeking preferences and behaviors. Gilovich (1983) observed that gamblers spent considerable time and energy explaining wins, but succinctly blamed luck or anomalous circumstances for losses. This bias towards emphasizing successful outcomes impedes learning and optimal decision-making.

Outcome bias is another cognitive bias that distorts decision-making. This is particularly true in elite sports, where managers enact substantial changes in strategy and decision-making based on small or random differences between winning and losing previous games (Lefgren et al. 2015, Gauriot and Page 2018). People tend to critique good decisions with bad outcomes, while approving of poor choices with favorable outcomes (Baron and Hershey 1988). It is often pleasurable for people to expound upon successes and surmise narratives of virtues that underpinned positive outcomes. This is particularly true for leaders who want to promote successes to brandish their professional reputations and accomplishments. However, an overemphasis on successful results leads individuals and organizations to undersample failure and develop biases (Denrell and March 2001, Denrell 2007). Winners tend to be deified, sometimes undeservingly. In contrast, losers are prone to being unfairly underestimated, shunned or forgotten. While unpleasant - and perhaps embarrassing if occurring publicly - failures tend to yield better learning and deeper knowledge than successes (Levitt and March 1988, Baumeister et al. 2001, Madsen and Desai 2010, KC et al. 2013 cf. Baum and Dahlin 2007). Failures create unique opportunities for sensemaking and learning from error (Maitlis and Christianson 2014). Good luck may be a very positive outcome in the shortterm. However, by eliminating failure and obfuscating weaknesses, good luck can also impede the development of organizational knowledge, while diminishing motivation to make needed changes and continue searching for means of improvement (Levinthal and March 1993).

Leaders are often ascribed excessive responsibility for failures and successes. For example, Khurana (2002) argued that excessive faith in leadership results in the exaggeration of the impacts CEOs have on companies. Similarly, Perrow (1984) argued that executives tend to be overblamed for failures. This 'extra' responsibility is an occupational hazard - or in prosperous times, a perquisite - of management 
careers. Liu and de Rond (2016) argued that leaders whose decisions are successful tend to be venerated as heroes, while those who failed are often treated harshly, even when decisions were identical and largely influenced by chance. Failure leads to exploration of new alternatives (March 1991, Audia and Goncalo, 2007) and deviation from previous choices (Baum and Dahlin 2007). Hence, frequent changes in leadership and personnel in highly competitive industries may not be surprising, even if such changes are sometimes myopic. Leadership positions may be lucrative and prestigious, but in high-stakes contexts, such roles can also be precarious. Leaders often function as organizational totems, where they absorb praise and/or criticisms for outcomes influenced by a variety of organizational and industry forces, which are often partially or wholly outside of their volition.

The fundamental attribution error (Jones and Harris 1967) is a cognitive bias particularly germane to performance evaluation. People tend to overattribute the outcomes of others as due to their personal and behavioral characteristics, while underestimating influences of situational factors, including luck. In turn, many people in organizations - including coaches and players in sports - are ascribed excessive credit or blame for luck-influenced outcomes that they had limited or no control over. Inwardly, people tend to attribute their own success to personal virtues and attributes, while attributing failures to external circumstances, including luck (Langer 1975, Miller and Ross 1975, Sims and Gioia 1984). Such biases may bolster self-confidence (which may or may not be beneficial, depending on the person and context), but also inaccurately inflate people's perceptions of their own competence. In contrast, people may not be as charitable - or at least invoke different biases - when evaluating the virtues and performances of others. Attribution theory suggests that lucky performers are lauded and overestimated, while the unlucky are prone to having their skill underestimated and being unfairly maligned.

The general theory being proffered and tested is that lucky outcomes will compel organizations to retain leadership and personnel. While beneficial in the short-term, luck will negatively influence future performance in two main manners. First, through "regression to the mean", since lucky outcomes are unlikely to sustain long-term, and organizations experience downward mobility sticking with overestimated 
previously lucky strategies and personnel. Second, luck will diminish future performance by encouraging the retention of mediocre or overestimated strategies, leaders and performers.

Hypothesis 1: Lucky organizations are more likely to retain personnel and leadership.

Hypothesis 2: Good luck will be conducive to poorer decisions and future performance.

Hypothesis 3: Decision making - in this case, personnel retention-mediates the relationship between luck and organizational performance.

\section{CASE STUDY: TEAM OUTCOMES AND CAREER TRAJECTORIES IN THE NATIONAL FOOTBALL LEAGUE}

Professional sports provide a unique opportunity - a sort of laboratory - to measure luck, as they involve elite-level competition performed publicly under fixed rules and intense scrutiny. This scrutiny yields a plethora of standardized, easily accessible data on team and individual performance. The National Football League (NFL) is a relevant context to examine organizational responses to high-stakes outcomes influenced by an amalgam of skill and luck. Competition in the NFL is what Larkey et al. (1997) defined as a skill-luck hybrid game. Skill is vital for success in the NFL, or any skill-luck hybrid game. However, there is also some degree of randomness - or luck - influencing competitive outcomes. Based on computer simulations and the predictive accuracy of leading algorithms and oddsmakers, Mauboussin (2012: 74-78) estimated that various sources of luck explain $48 \%$ of the variance in yearly NFL team win-loss outcomes. Popularized by Lewis' (2003) Moneyball, considerable progress has been made in recent years in operations research and sports analytics in regards to the scientific analysis of performance (Winston 2009). However, the NFL has lagged behind other professional sports in the adoption of analytically advanced organizational practices and game strategies (Weintraub 2015, Lindsey 2016). ${ }^{1}$

\footnotetext{
${ }^{1}$ The adoption of advanced analytical methods by sports franchises does not even necessarily mean that decisions will wholly be governed by analytics. Baumer and Zimbalist (2013) chronicled numerous decisions made by Billy Beane
} 
Relatedly, the NFL has historically been characterized by a culture where teams and players rarely strategically underperform in games, or 'tank.' Most or all NFL games are contested fiercely, even when they are inconsequential in the standings, or if losing carries the perverse incentive of improved future draft picks for a given team (Barnwell 2017a, Clark 2017). While this cultural norm may be irrational for franchises, it makes accurately assessing the quality and performance of teams easier. As of 2015, most NFL teams remained skeptical laggards with sports analytics (Seifert 2015). Over the time period of this study (1990-2015), it is expected that advanced sports analytics will rarely - if ever - have significantly influenced personnel or strategic decision-making for NFL franchises. This means that the decision-making analyzed in this study will be influenced by incomplete information, gut instinct, folk wisdom, cultural norms and other human idiosyncrasies. Thus, the NFL offers an ideal context to analyze how managers personally perceive and respond to success and failure, whether lucky or unlucky.

Liu and de Rond (2016) defined luck as when outcomes are influenced by chance, instead of wholly by skill or deliberate actions. Identifying specific sources of chance is challenging, particularly in skill-luck hybrid games, where it is often difficult to disaggregate the intertwined influences of skill and chance on outcomes. Empirically isolating and measuring luck in organizations is challenging. Often, skill is ascribed as an explanation for successes, overlooking or underestimating the role of luck (Barney 1997, Frank 2016). Making correct attributions of personal responsibility with outcomes is especially difficult, given emotional and cognitive biases in individuals when appraising both themselves and others (Myers et al. 2014). This article identifies specific luck-based factors that influence outcomes, but are completely or mostly beyond the control of team leadership and players. Further, luck plays an additional indirect role in influencing future performance and outcomes by altering incentives, experiences and learning. When outcomes are

and the Oakland Athletics - the focal general manager and team profiled in Moneyball - that contradicted sabermetric tenets. Another possibility is that even if management attempts to install analytics-based systems and decision-making, there may be resistance from coaches and players (e.g., McNear 2016). 
influenced by chance, the meritoriousness of strategies and performance can be misaligned with outcomes and experiences.

The NFL - and professional sports more broadly - is an excellent context to study decision-making in part because teams are organizations with off-seasons, providing punctuated points in time to evaluate previous performance and make personnel changes. Most player and coach changes occur in the off-season. This clear demarcation of performance and outcomes from managerial decision-making is rare in any empirical context. This article empirically measures four specific sources of luck in the National Football League: strength of schedule, Elo/DVOA luck, fumble recovery rates, and player injuries. Effects of these four luck-based factors on subsequent performance and personnel decisions are analyzed.

First, NFL teams have no control over their strength of schedule (i.e. the quality of teams they compete against over the course of the 16 game regular season). Playing more difficult opponents should generally result in fewer regular season wins. In turn, it is also expected that facing more difficult opposition will be conducive to coach and personnel changes, as decision-makers are swayed by outcomes influenced by the chance distribution of opponent quality.

The second measure of luck is the divergence of actual win totals from predicted win totals based on quantitative measures of team quality that account for schedule strength and margins of victory. Incorporating information including margins of victory, difficulty of opposition and yards gained, metrics like Elo and DVOA ratings improve the predictive accuracy for future team performance, compared to only considering simple wins and losses (Langville and Meyer 2012). The small sample size and asymmetric schedules of the NFL season can cause outcomes (wins) to diverge from actual team performance. This divergence is often difficult for leaders and stakeholders to recognize. In turn, it is expected that luckier teams which win more games than expected based on team quality will make relatively fewer team changes, as inflated outcomes result in an overestimation of existing strategies and personnel. 
The third measure of luck is team fumble recovery rate. Fumble recoveries in professional football are random, even though the turnovers - or lack thereof - that result from fumbles strongly influence game outcomes (Burke 2007, Lopez 2013). Fumble recovery can be identified as a source of luck since historically, offensive and defensive teams have been equally likely to recover a fumbled ball. Until recently, this information was a source of arbitrage for savvy gamblers. Las Vegas oddsmakers and naïve public bettors attributed excessive quality to teams with many fumble recoveries, while underestimating teams who were unlucky with fumble recoveries (Stoll 2012).

The fourth measure of luck is player injuries. Football is a violent, physically taxing game. Injuries that prevent players from playing in games or degrade their performance are inevitable. Some teams are more affected by injuries than others over the course of a regular season.

\section{METHODOLOGY}

\section{Data}

From a database of 769 NFL team seasons (all seasons for all teams from 1990-2015), effects of team outcomes (both performance and luck-based) on subsequent performance and personnel decisions are analyzed. Two quantitative measures of team quality are used: Elo and DVOA ratings. NFL Elo ratings were culled from the FiveThirtyEight.com Complete History of the NFL database. Team DVOA ratings were retrieved from the online Football Outsiders (2016) archives. Franchise yearly win-loss records, schedules, game statistics, as well as head coach and personnel changes were collected from pro-footballreference.com. Information on team injuries was acquired via a proprietary Football Outsiders database on Adjusted Games Lost, which tracked team injury reports from 2002-2015. Historical data on team fumbles and recoveries were culled from the fantasydata.com API.

\section{Dependent Variables}

Performance Outcomes. Due to inherent noise in elite sport competition - including the NFL - the best competitor does not necessarily win each individual contest (Lopez et al. 2018). In this study, a broad 
measure of luck is operationalized as the difference between a team's actual and predicted number of wins based on two quantitative team quality measures: Elo ratings and DVOA ratings (also see Pomeroy 2006, Barnwell 2017b). Elo ratings use strength of schedule and margin of victory to generate quantitative metrics of team quality. DVOA ratings use yardage gained and ceded in a game to generate estimates of team quality. Lucky teams win more games than predicted by their quality ratings due to close victories and easier schedules. Unlucky teams win fewer games than 'deserved' due to relatively unfavorable schedules and/or unfortunate distributions of scoring or yardage gains over the 16-game regular season. Predictions of the number of wins a team 'deserved' to have in a season were derived from the predicted win probabilities based on an OLS regression of the team quality rating (either Elo or DVOA) on yearly wins. With Elo and DVOA ratings, the positive or negative difference between actual and predicted wins denotes good or bad luck. Lucky teams have positive values of Elo and DVOA luck, winning more games than predicted. Unlucky teams have negative values; losing more games than their team quality predicted. Although the reward structures of sports revolve around simple wins and losses, quantitative metrics such as Elo and DVOA ratings outperform simple wins and losses in predictive ability (Langville and Meyer 2012). This suggests that such ratings provide a more accurate measure of team quality than simple wins and losses, even if the strategies and behaviors of players and coaches are oriented towards winning. ${ }^{2}$

\footnotetext{
${ }^{2}$ Holcomb et al. (2009) posited that competent organizations - both in professional football and in general - achieve competitive advantage by maximizing performance from limited resources. When considering positive or negative differences between actual wins and wins predicted by Elo/DVOA ratings, it could also be posited that competent leaders and organizations maximize their talent by consistently winning more games than their actual team quality suggests they should have. This is a reasonable hypothesis, and there may be some true individual differences between coaches and players regarding their ability to turn raw talent and statistics into wins. However, given the superior predictive ability of Elo/DVOA ratings vis-à-vis simple wins and losses, it is also reasonable to surmise that luck plays a large factor in explaining why - as per Figures $1 \mathrm{a}$ and $1 \mathrm{~b}$ - teams with identical win outcomes can have widely divergent talent levels.

In this context, two high-profile NFL coaches are worth considering as examples. Bill Belichick is one of the most successful and respected coaches in NFL history, having won five Super Bowls (as of 2018) as head coach of the New England Patriots. Andy Reid is known as an overall excellent coach with a particular weakness with clock management skills, although he is not the only NFL coach with such weaknesses (McKnight, 2016). Poor clock management is an important weakness when considering Elo/DVOA luck, since it can contribute to a team performing statistically well but diminishing its chances of winning games. Over the course of their careers, Belichick and Reid had similar luck outcomes, even though Reid is known for making strategic time management-related blunders in games. Both coaches have experienced similar relatively average luck in their careers. With considerable year-to-year variation, Reid's Elo average career Elo luck score is -0.11 wins/season, Belichick's is -0.37 wins/season. This is relatively middle-of-the-
} 
Elo Rating. Elo ratings were initially devised by Árpád Élö in 1960 to rank the quality of elite chess players. Since then, Elo ratings have been adapted to measure the quality of competitors in a variety of team sports (Langville and Meyer 2012). Silver (2014) adapted Elo ratings to predict NFL performance using margin of victory and difficulty of opposition to refine measures of team quality beyond simple wins and losses. Elo ratings are Bayesian and continually update based on results, moving scores upwards for victories (especially over stronger opponents) and downward for losses. Elo ratings are an excellent indicator of true team quality and have been found to be as accurate a predictor of future NFL results as any method, including Las Vegas gambling lines (Langville and Meyer 2012, Silver 2014).

DVOA Rating. An alternative measure of team quality is Defense-adjusted Value Over Average (DVOA). Winston (2009) identified DVOA as the preeminent analytics metric for football. DVOA rates teams based on every single play during the NFL season, comparing the outcome of every play in a game to a leagueaverage baseline based on situation, controlling for opposition quality (Football Outsiders 2016). DVOA is also unique in that it considers game circumstances when appraising the value of plays. For example, an eight yard gain may generally seem impressive. However, if that eight yard gain occurred on a 3rd-and-12 situation, such a play typically entails ceding possession of the ball and thus favors the opponent, who would have devised their defensive strategy accordingly. In contrast, a four yard gain would be assigned relatively high DVOA value if the play substantially improved the offense's chances of scoring.

road luck - as might be expected of coaches with very long careers (Reid: 17 years; Belichick: 21 years). The Elo luck values for both coaches would rank between $19^{\text {th }}$ and $20^{\text {th }}$ of 32 coaches in 2015 . DVOA luck tells a slightly different story. Belichick has a very average career DVOA luck value of 0.14 wins/season. In 2015, this would rank him between $15^{\text {th }}$ and $16^{\text {th }}$ of 32 coaches. Once again, this is not surprising for a long-tenured coach, and may be suggestive that even a very skilled coach cannot influence metrics like Elo or DVOA luck over the long term. Reid's career DVOA luck is -0.67 wins/season. This would place him between $18^{\text {th }}$ and $19^{\text {th }}$ of 32 coaches in 2015 . Given the length of Reid's coaching career, it might be possible that his poor clock management skills contributed to slightly below average DVOA 'luck' over the long-term.

A more thorough investigation of the relationship of quantitative skill ratings and reward structures (in this case, wins and losses) is beyond the scope of this article. However, given the small career effects for both Belichick and Reid and the wide year-to-year variation, this is evidence suggesting that individual coaching skill disparities with game management do not have a large impact on the Elo/DVOA measures of luck. 
Coach and Player Changes. NFL player contracts are unusually precarious for elite professional sports; even most multi-year contracts offer relatively little guaranteed money (Volin 2016). Thus, NFL teams have the flexibility to overhaul rosters annually with low transaction costs. Year-to-year changes in head coaches, team rosters and starting players were also compiled. In the event a head coach was fired midseason, a coach change is defined as when the head coach who starts a season with a team is different than the coach that started last year's season. Out of 769 NFL team seasons from 1990-2015, 169 coach changes occurred, not including temporary interim coaches. Player retention from year-to-year was operationalized in two ways. First, the number of players on a team's roster in consecutive years was measured. Second, to analyze year-to-year changes of important players on a team, the proportion of players who started at least nine games (over half of the regular season) for a team in consecutive years was also measured.

Strength of schedule. The difficulty of a focal team's opposition for the regular season was calculated by averaging the Elo and DVOA ratings of the opposition in each team's 16-game schedule from 1990-2015.

\section{Independent Variables}

Elo/DVOA Luck. These measures of luck are the positive or negative discrepancy between predicted and actual wins based on metrics of team quality. Advanced team ranking metrics (such as Elo and DVOA ratings) account for strength of schedule as well as margins of victory to gauge team quality. While measures of team quality and wins are correlated, there is still considerable variation in win totals among teams of similar quality. Elo and DVOA ratings were correlated .90 . Elo ratings were slightly more predictive of wins; correlated .93 with win totals, while DVOA ratings were correlated .86 with wins. As expected, higher quality teams - regardless of how quality is measured - win more games, although there is still variance in win outcomes between teams of similar quality. Luckier teams will win more games than predicted based on their Elo and/or DVOA rankings. Unlucky teams will win fewer games than expected based on their observed quality. For example, assuming equal win-loss records, a team with resounding wins and close losses should be of better quality than a team with narrow wins and blowout losses (Langville and Meyer 2012). The reward system of most sports and competition revolves around wins and losses, 
which is correlated with - but not identical to - team quality. Figures $1 \mathrm{a}$ and $1 \mathrm{~b}$ show there is considerable heterogeneity in team quality metrics among teams with identical numbers of wins (tie games were assigned a half-win).

-- Insert Figures 1a and 1b here --

Schedule Luck. The asymmetry of NFL schedules, where some teams face more challenging opposition than others, is another factor which causes win totals and team quality metrics to diverge. Due in part to the violent nature of football, NFL games in a season are only 16 games long. This is in contrast to the 38 games of the English Premier League, 82 games of the National Basketball Association and National Hockey League and 162 games of Major League Baseball. This small sample size means that skill-based outcomes in the NFL will be relatively noisy. The short season also creates the danger of decision-makers overestimating information provided by a small sample (Tversky and Kahneman 1971, Rabin 2002). As Pauley (2018) argued, an NFL franchise is five times more likely to replace its coach after a 6-win season than a 10-win season, even though both are equally likely outcomes for a team of average (8-win) true quality. A symmetrical format where every team plays every other team in the league home and away is infeasible, given that there were 28-32 teams in the NFL over the period studied. The NFL attempts to give stronger teams a more difficult schedule the following year. However, the correlation between previous year wins and schedule strength was only .13, suggesting that luck is a major factor in determining schedule strength. ${ }^{3}$ Miller (2016) chronicled the largely random network ties between teams in historical NFL

\footnotetext{
${ }^{3}$ Since 2000, and the appointment of head coach Bill Belichick, the New England Patriots have been the winningest team in the NFL. Germane to the preceding discussion of luck in Belichick's career, over the course of this dominant run, the New England Patriots have enjoyed very average schedule difficulty. This illustrates the weak relationship between success and future schedule strength. Since 2000, the Patriots average opponent had an Elo rating of 1504.08 (a theoretically average team is rated 1500). Despite limited 'equalizing' schedule NFL policies that attempt to give stronger teams more difficult schedules, the New England Patriots have played schedules of relatively average difficulty since their first Super Bowl win in 2000.
} 
schedules. Since NFL teams play asymmetric schedules, some teams will enjoy easier opposition than others. $^{4}$

Fumble Luck. Turnovers via fumble (i.e. when a player accidentally drops the ball during play) are influential on game outcomes, since they involve taking away an offensive possession from one team and granting an extra offensive possession to their opponents. ${ }^{5}$ Better teams and players will generally fumble less, due to strong ball control and/or ensuring that ball carriers are tackled less often and with less force. However, all football teams fumble the ball at some point; fumbles are normal accidents, as per Perrow's (1984) terminology. Further, once the pointy football is dropped to the ground, fumble recoveries are fairly random outcomes. Based on records of 20,368 fumbles over 13,265 regular season games played from 1990-2015, fumbling teams recovered the football $51.16 \%$ of the time. In turn, expected fumble recoveries were operationalized as .5116 recoveries for each team fumble in a game and .4884 recoveries for each opponent fumble. Fumble luck is defined as the difference between actual and expected fumble recoveries. Some teams are luckier with recovering fumbles than others over a course of a season. Fumble luck ranged from 10.47 fumble recoveries above expectation (1994 New York Giants) to 11.56 fumble recoveries below expectation (1994 Cincinnati Bengals).

Injury Luck. Player injuries are another type of normal accident that affect team outcomes. Injuries generally harm team performance, since the replacement player is generally of lower quality than the injured player. Further, incorporating a reserve player into a new role hurts team continuity and performance (Groysberg et al. 2008, Stuart 2017). Throughout each week of the NFL regular season, the hazard rate for player injuries is fairly constant (Binney 2015). Over the course of the season, some teams will be luckier than others and experience relatively fewer and less severe injuries to important players. Based on playing

\footnotetext{
${ }^{4}$ As another example of how difficult opposition can suppress win outcomes yet bolster quality ratings, chess grandmaster Magnus Carlsen achieved the highest Elo rating in history and currently remains the top-ranked player in the world. However, his career winning percentage is only 62.5\%. (Cohen 2017)

${ }^{5}$ Barnwell (2011) presented evidence that most - if not all - turnovers are random events in NFL football.
} 
records and weekly team injury reports, Football Outsiders devised the Adjusted Games Lost statistic to measure the extent to which a team is affected by injuries (Kacsmar 2016). Adjusted Games Lost accounts for two types of injury effects. First, the most obvious effect of injuries is when a player misses a game due to injury. Adjusted Games Lost measures games missed by starters and other important players; injuries to peripheral or bench players are assumed to be less consequential to team performance. Second, Adjusted Games Lost also accounts for performance degradation when an injured player participates in a game, despite having been listed as "doubtful" or "questionable" to play in the weekly team injury report.

\section{Control Variables}

Annual Draft Pick Value. The NFL has an annual redistributive rookie draft, where teams with the poorest records get favorable choices to restock their teams with newly-eligible college-level players. To account for this redistributive institution, the value of annual draft picks for each team were calculated based on a lowess smooth of Career Approximate Value (CAV) of draft picks on football-reference.com for players drafted from 1990-2005. Reflecting previous work on the NFL draft (Holcomb et al. 2009, Massey and Thaler 2013), analysis revealed that the value of draft picks declines exponentially through multiple rounds of the draft.

Total Coach Games with Team; Coach Win Percentage with Team. For these measures, coach records accrued during pre-1978 14-game seasons, and strike-shortened seasons $(1982,1987)$ were pro-rated over a 16-game schedule.

\section{RESULTS}

Effects of lucky and strategic factors are analyzed for various team performance outcomes, as well as coach and player careers.

Table 1 presents summary correlations of luck and performance variables. 


\section{Influence of Luck on Team Outcomes}

Table 2 reports the effects of various strategic and luck-based factors on NFL yearly win outcomes.

-- Insert Table 2 here --

The univariate results presented in Table 2 show that all listed variables have a significant effect on team wins. Lucky factors have similar significant effects on win outcomes as do strategic (player/coach retention) and institutional (draft) factors. Roster and starter retention are largely strategic choices made by franchises. In comparison, most of the remaining variables involve little to no team control, and thus can be understood as 'lucky' factors.

While starter and player retention are significantly negatively associated with future wins in the univariate models, this relationship changes in the multivariate models. In contrast, effects for overall roster retention become non-significant, while starter retention is significantly associated with future wins when accounting for other variables in the model. When team quality and schedule strength is included in the models, personnel and coach retention are shown to have a significantly positive effect on performance. In a sport that requires coordinated teamwork like football, there are performance benefits associated with continuity and accumulated experience (Groysberg et al. 2008). In turn, personnel changes tend to cause a decline in performance for good teams, although talent upgrades - often via the redistributive NFL player draft - may help overcome the negative effects of losses in continuity for weaker teams. Overall, both strategic and lucky factors show significant influences on future outcomes for NFL teams.

-- Insert Table 3 here --

\section{Influence of Luck on Coach Retention}

Table 3 reports logistic regression analysis and odds ratios of factors conducive to head being retained from one season to the next. As expected, teams with fewer wins are more likely to change their coach. Less lucky teams are also more likely to change coaches. In the univariate models, most luck-based 
factors have a significant effect on the likelihood of a team changing head coaches. The multivariate models reported in Table $3 \mathrm{~b}$ show that after the addition of relevant control variables, overall Elo and DVOA luck remain conducive to coach retention. Although the significant effects of schedule strength attenuate in the multivariate model when included with Elo/DVOA luck, it is important to remember that schedule strength is a component of Elo/DVOA luck. Elo and DVOA luck are correlated .49 and .40 with schedule strength respectively. Power rankings like Elo and DVOA luck correct for the difficulty of opposition, even though most conventional metrics do not. As expected, coaches with high winning percentages with their team are much more likely to be retained. In contrast, coaches with longer tenures with teams are actually slightly less likely to be retained, suggesting that there may be a "shelf life" for coaching careers in the NFL.

\section{Influence of Luck and Performance Outcomes on Yearly Personnel Changes}

Since coaching careers are affected by luck, this raises the question of whether player careers are also impacted by luck. Table 4a reports effects of team characteristics on the likelihood of retention of all players on a team's roster from one season to the next. Table $4 \mathrm{~b}$ reports the likelihood of teams with players who start at least nine games in consecutive years.

-- Insert Tables $4 \mathrm{a}$ and $4 \mathrm{~b}$ here -

Results for player retention are similar to those for coach retention. As expected, winning is conducive to more personnel retention. As was the case with coach retention, luckier teams make fewer changes to the player roster. In particular, even though players have no control over the difficulty of their team's schedule, schedule difficulty has a significant negative effect on player retention. More difficult schedules are conducive to more personnel changes in the subsequent year. Injuries also have a consistently significantly effect on player changes. These changes could be due to disappointing game outcomes experienced after injuries. In turn, in addition to the physical pain, players also bear blame, risks and consequences for injuries. While replacing injured and injury-prone players is not surprising, these results reveal career 
incentives for players to conceal and play through injuries. These incentives regarding player health may not be in the short or long-term interests of players or their teams.

\section{Efficacy of Personnel Changes}

A key question regarding personnel and coach changes is whether installing new leadership or personnel improves performance. This is particularly important when such changes may be influenced by organizational learning from misleading luck-influenced outcomes. In turn, strategic team decisions - such as personnel retention - may mediate the negative relationship between luck and future outcomes.

To examine possible mediating effects of personnel retention on the relationship between luck and performance outcomes, Sobel-Goodman mediation tests were performed. Sobel-Goodman mediation tests quantify the proportion of the total effect explained by the mediating variable (MacKinnon et al. 2002). In this case, player retention is hypothesized to mediate the negative relationship between luck and subsequent performance. Figure 2a illustrates a theoretical model of potential causal pathways between luck, retention and performance. Figure $2 \mathrm{~b}$ reports results of a Sobel-Goodman mediation model based on specific empirical measures of Elo luck, retention and performance.

-- Insert Figures $2 \mathrm{a}$ and $2 \mathrm{~b}$ here --

Regression analysis was used to test the hypothesis that player retention mediates the effect of previous year Elo luck on annual win change. Figure $2 \mathrm{~b}$ reports a partially mediated relationship. Results show that previous year luck had a significant negative effect on win change $(b=-1.217$, SE $.105, p<.001)$ and a significant positive effect on player retention $(b=.587, \mathrm{SE} .137, \mathrm{p}<.001)$. When regressing win change on the mediator (roster retention) and previous year's luck, both player retention $(b=-.167$, SE $.027, \mathrm{p}<.001)$ and previous year luck $(\mathrm{b}=-1.119, \mathrm{SE} .104, \mathrm{p}<.001)$ had significantly negative effects on win change. This means that $8.02 \%$ of the total effect of previous year luck on win change is mediated by player retention. Using Elo strength of schedule change alone as the independent variable in the model yields similar - but smaller in magnitude - results, mediating $6.13 \%$ of the total relationship between Elo 
luck and win change. Substituting DVOA values of previous luck and schedule strength in the model for Elo values also yields similar results to those reported in Figure $2 \mathrm{~b}$. Player retention mediates $7.6 \%$ of the significantly negative relationship between previous DVOA luck and win change. DVOA schedule strength mediates $6.31 \%$ of the relationship between previous luck and win change.

\section{DISCUSSION}

Results show that various luck-based factors - in this case, Elo/DVOA luck, schedule strength, fumble luck and injuries - significantly impact organizational performance and subsequent decisionmaking. Organizations and players have little to no control over these luck-based factors, yet they influence game outcomes, careers and incentives for players, coaches and franchises alike. Hypothesis 1 was supported. Lucky factors were significantly positively associated with player and coach retention. As a rule, firing coaches or cutting players for performing below aspirations - or rewarding personnel for performing above aspirations - seems reasonable. However, making personnel changes due to lucky factors (e.g., difficult schedules, poor fumble recovery rates) is much less defensible, both from fairness and organizational strategy standpoints. It appears that over the period of analysis (1990-2015), most - if not all - NFL franchises were influenced by lucky factors and outcomes when considering whether to fire or retain personnel. This raises concerns about organizational meritocracy, as well as revealing a means by which NFL franchises squander value via personnel decisions. If management simply considers outcomes (in this case, wins and losses) to gauge team and personnel performance, this will contribute to the retention of less-talented lucky personnel and the loss of talented unlucky personnel. Losing talent - potentially ceding valuable underestimated personnel to rivals - will underpin diminished future performance. In turn, appropriately accounting for luck and distinguishing causal relationships with skill and performance are potential sources of competitive advantage for organizations.

Hypothesis 2 was also supported. Teams that experienced higher luck were more likely to experience a decline in performance outcomes (i.e. wins) the following year. This raises the question of which mechanisms underpin performance declines following lucky team outcomes. At least some of the 
observed performance declines following lucky seasons should be attributable to a regression to the mean. Teams with inflated win outcomes relative to their actual talent are unlikely to sustain such outcomes over the long-term. However, player retention is a mediating variable that partially mediates a small proportion of the relationship between luck and future performance. Thus, there is some support for Hypothesis 3 . Lucky outcomes appear to induce distorted learning and suboptimal personnel decisions, which also degrades future performance.

Although Elo/DVOA luck only mediated a small proportion of the relationship between luck and performance - roughly $8 \%$ - luck is difficult to empirically isolate. The empirical sources of luck examined in this study are likely only the "tip of the iceberg" of luck in the NFL. Other factors affecting NFL team performance strongly or entirely influenced by luck include rookie player evaluation (Massey and Thaler 2013, Paine 2014, R_Thaler 2018), plays with unusually large yardage gains (Connelly 2013, MasseyPeabody 2017), turnovers (Hale 2018), “red zone” clutch performance (Barnwell 2016), distribution of rest days between games (bburkeESPN 2018), opponent injuries, weather, officiating, travel schedules and propitious play calling. Some of these sources of luck are difficult - if not impossible - to precisely identify, operationalize and isolate from skill-based components. Thus, this research offers a sample of lucky factors, showing how luck - whether directly observable or not - influences organizational decisionmaking performance. Performance declines following lucky outcomes explained in part by organizational learning and decision-making, as opposed to being wholly explained by regression to the mean.

Player and coach retention results show evidence of the fundamental attribution error (Jones and Harris 1967), where evaluators overattribute outcomes to the talents (or lack thereof) of individuals, as opposed to structural or extraneous influences. Luckier outcomes were conducive to the retention of coaches and players. Less lucky teams were more likely to replace coaches and players. In turn, people are credited or blamed for accomplishments that were at least in part out of their control. Unlucky coaches and personnel were evaluated harshly for poorer outcomes. As attribution theory predicts, people tend to attribute their own successes to personal virtues and attributes, while attributing personal failures to external 
circumstances (Miller and Ross 1975, Gilovich and Douglas 1986). Further, people generally underestimate external 'tailwinds' aiding their successes, while overestimating 'headwinds' militating against their interests (Davidai and Gilovich 2016). Schedule difficulty - which can function as a headwind or a tailwind - is a specific example of a 'lucky' uncontrollable factor which influences organizational decision-making and by extension, player and coach careers.

Given the importance and influence of luck, inferring quality based on results alone is rarely optimal. However, luck is often used as an excuse for disappointing skill-based outcomes and can easily be misspecified. Merely acknowledging the existence of luck is not necessarily helpful since luck can undermine responsibility among decision-makers (Pritchard and Smith 2004). People often use luck as an excuse for skill-based underperformance following disappointing outcomes. In fact, ignorance of the existence of luck - and relying solely on outcomes for information - may actually be preferable for the naïve, since they are especially prone to misunderstanding luck-based feedback. The equalizing and misinforming nature of luck is a mechanism by which the less-skilled not only remain ignorant of their shortcomings and mistakes, but also unwilling and unable to improve (Kruger and Dunning 1999).

Since luck has the potential to erode responsibility, this raises dilemmas of whether and how luckbased explanations for outcomes should trickle down the organizational hierarchy. For example, while fumble recoveries in football are random outcomes, this is predicated on both sides fiercely contesting the ball. Fumble recoveries are an especially savage part of an already violent game, often involving extralegal tactics by players attempts to coerce rivals into ceding the ball, including arm-twisting, finger-breaking and punching (Brown and Emmons 2012). The notion that fumble recoveries are - at least to some extent influenced by luck may dampen the motivation of players to fight zealously over fumbled balls, thus diminishing team performance and outcomes. Knowledge of luck may improve managerial decisionmaking, but it may be wise to selectively release such information down the organizational hierarchy.

Paradoxically, experiencing good luck with outcomes may be dangerous for the long-term job security of players and coaches. Strang and Patterson (2014) found that managerial firings in professional 
baseball are most strongly influenced by recent outcomes, falling with success, rising with failures and adjusting for history-based outcomes. People evaluate outcomes relative to previous states and endowments (Tversky and Kahneman 1991). Organizations adapt incrementally to positive and negative feedback, oriented towards targets or aspirations (March and Shapira 1992, Moliterno et al. 2014). In turn, aspiration levels influence organizational learning and decision-making (Cyert and March 1963). Outcomes below aspiration levels trigger search and change (Simon 1959, Greve 1998). Consequently, lucky outcomes encourage persistence with overestimated strategies and personnel while raising aspirations above true talent levels. The likely - if not inevitable - regression to the mean renders future outcomes below those inflated aspirations more jarring. Lucky factors influencing performance outcomes is a mechanism underpinning the Peter Principle (Lazear 2004), where people are promoted to levels of incompetence. Successful outcomes may provide feedback to promote or retain existing personnel. When positive outcomes are influenced by chance, if leaders do not recognize and correct for these influences, this will result in the promotion of inferior talent, and poorer long-term performance.

Undeserved outcomes above aspirations raise the challenge of whether and how organizations can learn effectively in times of lucky buoyancy. Can executives and organizations legitimately make changes after successes (if outcomes were perceived as lucky) or retain previously failing personnel and strategies (if outcomes were perceived as unlucky)? Such moves are risky for executives, who will look especially bad if the changes - or lack thereof - yield stagnant or regressing outcomes. Such moves could confuse and discomfit employees - in this case, players - who may not feel fairly treated if changes are made after successful outcomes, or if failures appear to be treated with apathy or impunity. Appropriately assigning accountability and fairly distributing awards for performance is challenging in organizations (Lerner and Tetlock 1999, Maltarich et al. 2017). This is especially true in a team game like football, where isolating the exact contributions of individuals to outcomes is difficult, as is determining the precise roles skill and luck played in influencing those outcomes. When workers and teams are not directly rewarded for outcomes, this could be a threat to perceived fairness and meritocracy in the organization. This raises 
dilemmas regarding distributive justice, especially when firms pay employees for performance and make retention decisions based on outcomes that are at least partially influenced by chance factors. A lack of control over outcomes is conducive to perceptions of unfairness when employees are rewarded for those outcomes (Folger and Konovsky 1989, Milkovich et al. 2013). Given that luck is omnipresent in many industries, fairly compensating employees is a challenge faced by many organizations. Like with learning from luck, dealing with this dilemma skillfully - and keeping employees happy despite uncontrollable randomness in outcomes and compensation - is another potential source of competitive advantage for organizations that identify, understand and manage luck skillfully.

Accurately distinguishing skill and luck is often challenging. Consequently, people and institutions often use outcomes as a proxy for skill. In fairness, skill is generally correlated with outcomes. However, depending on the context, skill is not necessarily the only - or even primary - factor influencing outcomes. When talent differences are marginal - as is often the case with high-level competition - luck becomes the dominant influence on outcomes (March and March 1977, Mauboussin 2012). Kim et al. (2017) argued that a substantial portion of variation in CEO performance is due to luck, and true skill differences between most leaders are likely small. However, when luck or randomness is involved, focusing on results alone is myopic and will result in distorted learning. Of course, precisely identifying skill and luck components influencing outcomes is often difficult. This challenge is compounded by cognitive biases such as risk aversion and outcome bias, in addition to the tendency to overcredit leaders for both successes and failures. The rewarding of luck is common in many contexts. In a survey of S\&P 500 companies, Levy (2016) estimated that $90 \%$ of CEO pay-for-performance is based on luck. Analogously, executive compensation in the oil industry fluctuates with the price of oil (Bertrand and Mullainathan 2001), even though executives have no control over those price changes. Likewise, oil prices affect the re-election prospects of governors of oil-producing states (Wolfers 2007). In turn, employees often bear some or all of the structural risks in risky industries and contexts; this can entail occupational hazards or perquisites, depending on whether outcomes are favorable. 


\section{Perverse Incentives}

As shown, luck creates problems for organizations by compelling them to learn from distorted outcomes. However, luck may create additional challenges for both leaders and subordinates via perverse incentives. In particular, risk aversion and scapegoating are potential suboptimal consequences of luck and organizational responses to lucky outcomes.

Risk aversion. As shown in this study, various forms of bad luck influence franchises to fire head coaches. In turn, it may not be surprising that football coaches are notoriously risk-averse with game strategy (Salfino and Chairusmi 2016). Professional football coaches often squander significant value by being excessively risk-averse with game strategy (Romer 2006, Walker et al. 2018), particularly when they experience job insecurity (Owens and Roach 2017). For a game and profession characterized by masculine hubris, overwork and micromanagement, this is an ironic phenomenon. Given the association of overconfident risk taking with hypermasculinity (Barber and Odean 2000), this is especially surprising. Richard Thaler lamented that years after Romer's 2006 article, coaches have still not updated game strategies, despite the value such risk aversion squanders (R_Thaler 2015, Morris 2016).

However, if coaches are aware that bad luck endangers their jobs, attempting to minimize or control luck may be an understandable - and possibly rational - preference, even if such strategies squander value. Leaders tend to perceive downside risks more vividly than upside risks (March and Shapira 1987). This is related to the tendency of leaders to be overblamed for failures. Generally, people generally tend to be averse to risk and uncertainty, especially when less uncertain options are present (Fox and Tversky 1995). Risk-averse decisions by football coaches - such as kicking on fourth-and-short situations - eliminate shortterm downside risk. Further, by conforming to traditional risk-averse rubrics in game strategy, coaches also inure themselves from criticism. ${ }^{6}$ An organizational culture that identifies sources of luck and variance, and

\footnotetext{
${ }^{6}$ In 2018, when questioned about his risk-averse strategies on fourth downs, Tampa Bay Buccaneers head coach Dirk Koetter replied, "The percentages say you should go for it almost every time. We've studied the analytics on it and the problem with looking at it like that - those are all looking at all fourth downs over the course of the season. You might get three in a row, but if I don't get it in this particular game, we might be losing, and I might be out of here."
} 
supports decision-makers choosing high-variance but profitable strategies, would enable more optimal strategies and improve outcomes (Thaler 2015: 294).

Scapegoating. Burke (2017) found that losing NFL teams gained 1.6 wins on average in the following season, regardless if they fired or retained their head coach (also see Lopez 2017). This could be attributed to the redistributive structure of the NFL (rookie draft, salary cap militates against teams stockpiling talent) as well as regression to the mean for the unlucky. This result resembles previous studies in numerous sports finding that coach changes rarely have a long-term positive impact on team performance (Eitzen and Yetman 1972, Koning 2003, De Paola and Scoppa 2011, Barnes 2013). Losing teams may be relatively likely to improve after personnel changes due to separate redistributive mechanisms in the NFL and/or simple regression to the mean. Since unlucky coaches and players on unlucky teams are more likely to be replaced, the likely improvement (or regression to the mean) of unlucky teams in the following season will tend to make these changes look wiser and more effectual than they actually were.

Even if coach changes are of little value to franchises, luck provides an incentive for organizations to make such moves for reasons beyond appeasement or catharsis for disappointed team stakeholders. Losing NFL teams tend to regress to the mean the following year (Burke 2017). If a losing team replaces their head coach, it allows management to take credit for a shrewd move that seemingly improved performance. As Cohen and March (1974) observed, any intervention undertaken when $X_{1}$ - in this case, luck or wins - is unusually low will be associated with a performance increase. Over the long-term, frequent myopic coach and player changes will trap naïve leaders and franchises who repeatedly respond to these short-term luck-influenced signals. As Gamson and Scotch (1964) argued, "[t]he firing of the field manager...is a convenient, anxiety-reducing act which the participants in the ceremony regard as a way of

(Smith 2018). In other words, Koetter is willing to forego a new strategy with positive expected value because he believes he would be more likely to be punished for failures vis-à-vis a traditional risk-averse game strategy. 
improving performance, even though real improvement can come only through long-range organizational decisions."

\section{CONCLUSION}

Kahneman et al. (2016) argued that individuals and organizations incur substantial costs because judgments are often influenced by irrelevant factors. Lucky outcomes - whether favorable or unfavorable - make those irrelevant factors appear salient and effectual. This case study showed how luck influenced the decision-making of NFL teams and by extension, the incentives and careers of coaches and players. Coaches and players were more likely to be retained after less lucky seasons, even though they had no control over the luck-based factors which inflated team win outcomes. Lucky teams tended to experience downward mobility in following years. Part of this is due to regression to the mean, since luck is usually not sustainable long-term. However, this research presented evidence that luck also negatively influences future performance by distorting optimal learning and affecting personnel decisions.

The NFL context raises numerous possibilities for future research on luck and decision making, both in sports contexts and beyond. ${ }^{7}$ The NFL - and most North American professional sports - has a redistributive structure, where salary caps and rookie drafts buoy the future performance of low-performing teams. This is in contrast to the hierarchical, Darwinian structures of most European professional sports, where top teams have disproportionately more resources and weaker teams face relegation to lower leagues (Kuper and Szymanski 2009). This exemplifies the contrast between Matthew Effects (Merton 1968, Kim and King 2014) and Mark Effects (Bothner et al. 2011), where social systems either amplify or mitigate future inequalities between competitors based on previous outcomes. Although redistribution is not a form

\footnotetext{
${ }^{7}$ Different levels of analysis in sports analytics is another line of future inquiry. For example, To et al. (2018) examined NFL play-by-play data to analyze risk-taking behavior in competition. This level of analysis illuminates heat-of-themoment decision-making by leaders. Applied to the study of how luck influences learning, play-by-play data could examine whether (for example) a coach will remove a player who fumbles the ball and loses possession, as opposed to a player who fumbles and retains possession. Likewise, a risk-averse coach might stop running the ball after a nonrecovered fumble, but would continue to run the ball immediately following a recovered fumble.
} 
of luck, it is an analogous non-controllable external factor affecting organizational feedback and outcomes. Non-redistributive systems would provide a better context to examine possible deleterious effects of bad luck on learning and decision-making. Another question for future analysis is how different redistributive systems affect learning and decision-making. For example, contexts with strong Matthew Effects may underpin positive relationships between luck and future performance, despite the learning distortions of luck and cumulative advantage. ${ }^{8}$

The continued development of sports analytics - as well as the recent proliferation of complex "big data" on elite sports performance - offers substantial opportunity for further examination of how luck influences learning and performance. Various lucky forces can be operationalized in other sports and organizations. For example, in baseball, batting average on balls in play (BABIP) and clutch hitting affect individual and team outcomes, but are strongly luck-influenced (Peta 2013). Hockey has Corsi ratings, soccer has expected goals. Beyond the high-profile context of elite-level sports, all types of organizations are capable of devising luck-corrected measures of team and individual performance. Further, the controls of laboratory study - where degrees and types of luck and redistribution can be manipulated - would be an excellent complement to large-scale observational data of elite sports performance. Devising appropriate people and group analytics to make fairer appraisals of performance in a luck-influenced world is a potential next frontier for both sports analytics and organization theory. Such improved appraisals of performance and understanding of causal relationships involving luck could underpin improved decision-making and future performance for both individuals and their organizations.

In summary, organizational strategies, personnel and careers are often influenced by luck. This violates most cultural norms of meritocracy and can induce suboptimal organizational choices, as well as diminished future performance. Distinguishing signal from noise is a challenge, but also a potential source

\footnotetext{
${ }^{8}$ Social systems with strong cumulative advantage (Matthew Effects) and high luck may be an additional mechanism conducive to the phenomenon observed by Denrell and Liu (2012) where "top performers" are among the least competent competitors in the system. The poor learning inculcated by high luck would be obfuscated by the advantages garnered via cumulative advantage.
} 
of arbitrage and competitive advantage. Noise and luck aid the less-skilled in the short-term, but also offer arbitrage opportunities for the skilled, who learn more accurate lessons from feedback that obfuscates causal relationships between performance and outcomes. Paradoxically, luck can create new types of skill. In skillluck hybrid contexts, both good and bad luck can be dangerous. Avoiding luck - whether good or bad altogether might be the luckiest outcome of all. 


\section{WORKS CITED}

Argote L (2013) Organizational Learning: Creating, Retaining and Transferring Knowledge. New York: Springer.

Argote L, Beckman SL, Epple D (1990) The Persistence and Transfer of Learning in Industrial Settings. Management Science, 36: 140-154.

Argote L, Miron-Spektor E (2011) Organizational Learning: From Experience to Knowledge. Organization Science, 22: 1123-1137.

Audia PG, Locke EA, Smith KG (2000) The Paradox of Success: An Archival and a Laboratory Study of Strategic Persistence Following Radical Environmental Change. Academy of Management Journal, 43(5): 837-853.

Audia PG, Goncalo JA (2007) Past Success and Creativity over Time: A Study of Inventors in the Hard Disk Drive Industry. Management Science, 53: 1-15.

Barber B, Odean T (2001) Boys will be boys: gender, overconfidence and common stock investment. Quarterly Journal of Economics, 116: 261-292.

Barnes H (2013) Does it make statistical sense to sack a football manager? BBC Magazine, August 17.

Barney J (1997) On flipping coins and making technology choices: Luck as an explanation of technological foresight and oversight. In Garud, R., Nayyar, P.R., and Shapira, Z. (Eds.):

Technological Innovation: Oversights and Foresights, 13-19. Cambridge: Cambridge University Press.

Barnwell B (2017a) A tanking guide to the NFL, and a warning. http://www.espn.com/nfl/story//id/19652764/tanking-nfl-advantages-disadvantages-worth-newyork-jets-cleveland-browns-2017

Barnwell B. (2017b) NFL teams most likely to improve -- and decline -- in 2017. http://www.espn.com/nfl/story/_id/20199657/nfl-teams-likely-improve-decline-2017-season-billbarnwell-pythagorean-expectation

Barnwell B (2016) "NFL's best, worst in the red zone, and what it means for 2016." http://www.espn.com/nfl/story/_/page/BarnwellNFLPreview160729/nfl-best-worst-red-zonemeans-2016-season

Barnwell B (2011) Has the Steel Curtain Gone Soft? http://grantland.com/features/has-steel-curtain-gone$\underline{\text { soft/ }}$

Baron J, Hershey JC (1988) Outcome bias in decision evaluation. Journal of Personality and Social Psychology, 54: 569-579.

Baum JAC, Dahlin KB (2007) Aspiration Performance and Railroads' Patterns of Learning from Train Wrecks and Crashes. Organization Science, 18: 368-385.

Baumer B, Zimbalist A (2013) The Sabermetric Revolution: Assessing the Growth of Analytics in Baseball. Philadelphia: University of Pennsylvania Press.

bburkeESPN (2018) NFL has done a much better job evening out the pain with the schedule this yr. IND has the worst net rest differential with -12 days and 3 games vs opponents coming off their bye. Last season NYG was -22 days with 4 opponents coming off byes. April 20. [Tweet] 
Baumeister RF, Bratslavsky E, Finkeneuer C, Vohs KD (2001) Bad is stronger than good. Review of General Psychology, 5: 323-370.

Bertrand M, Mullainathan S (2001) Are CEOs Rewarded for Luck? The Ones Without Principals Are. Quarterly Journal of Economics, 116: 901-932.

Binney ZO (2015) NFL Injuries Part II: Variation Over Time. http://www.footballoutsiders.com/statanalysis/2015/nfl-injuries-part-ii-variation-over-time

Bothner MS, Podolny JM, Smith EB (2011) Organizing Contests for Status: The Matthew Effect vs. the Mark Effect. Management Science, 57(3): 438-457.

Brown D, Emmons M (2012) Dirty deeds: What goes on beneath the NFL pile. San Jose Mercury, Jan. 4.

Burke B (2017) Does firing the head coach actually lead to more wins? http://www.espn.com/nfl/story//id/18400460/does-firing-head-coaches-nfl-lead-more-wins-2016

Burke B (2007) Advanced Football Analytics: Fumbles and Fumbles Lost. Accessible: http://archive.advancedfootballanalytics.com/2007/04/fumbles-and-fumbles-lost.html

Carley KM, Lin Z (1997) A Theoretical Study of Organizational Performance Under Information Distortion. Management Science, 43(7): 976-997.

Clark K (2017) The NFL's Tanking Nightmare. https://www.theringer.com/2017/6/16/16077336/nfltanking-nightmare-new-york-jets-cleveland-browns-competitive-balance-6c9f3937811b

Cohen B (2017) A Chess Novice Challenged Magnus Carlsen. He Had One Month to Train. Wall Street Journal, Nov. 17.

Cohen MD, March JG (1974) Leadership and Ambiguity: The American College President. McGrawHill, New York.

Connelly B (2013) Study Hall: College Football, Its Stats and Its Stories. Seattle: CreateSpace.

Cyert RM, March JG (1963) A behavioral theory of the firm. Englewood Cliffs: Prentice Hall.

Davidai S, Gilovich T (2016) The headwinds/tailwinds asymmetry: An availability bias in assessments of barriers and blessings. Journal of Personality and Social Psychology, 111(6): 835-851.

De Paola M, Scoppa V (2012) The Effects of Managerial Turnover: Evidence from Coach Dismissals in Italian Soccer Teams. Journal of Sports Economics, 13: 152-168.

Denrell J (2007) Adaptive Learning and Risk Taking. Psychological Review, 114: 177-187.

Denrell J (2003) Vicarious Learning, Undersampling of Failure, and the Myths of Management. Organization Science, 14: 227-243.

Denrell J, Liu C (2012) Top performers are not the most impressive when extreme performance indicates unreliability. Proceedings of the National Academy of Sciences, 109: 9331-9336.

Denrell J, Fang C, Liu C (2015) Chance Explanations in the Management Sciences. Organization Science, 26: 923-940.

Denrell J, March JG (2001) Adaptation as information restriction: the hot stove effect. Organization Science, 12: 523-538.

Eitzen DS, Yetman NR (1972) Managerial Change, Longevity, and Organizational Effectiveness. Administrative Science Quarterly, 17: 110-116. 
Feather NT (1969) Attribution of responsibility and valence of success and failure in relation to initial confidence and task performance. Journal of Personality and Social Psychology, 13: 129-144.

Fischer-Baum R, Silver N (2016) The Complete History of the NFL. http://projects.fivethirtyeight.com/complete-history-of-the-nfl/

Folger R, Konovsky MA (1989) Effects of Procedural and Distributive Justice on Reactions to Pay Raise Decisions. Academy of Management Journal, 32(1): 115-130.

Football Outsiders 2016. Team Efficiency Ratings. http://www.footballoutsiders.com/stats/teameff

Fox CR, Tversky A (1995) Ambiguity aversion and comparative ignorance. Quarterly Journal of Economics, 110: 585-603.

Frank RH (2016) Success and Luck. Princeton: Princeton University Press.

Gamson WA, Scotch NA (1964) Scapegoating in Baseball. American Journal of Sociology, 70: 69-72.

Gauriot R, Page L (2018) Fooled by performance randomness: over-rewarding luck. https://ideas.repec.org/p/qut/qubewp/wp049.html

Gavetti G, Greve HR, Levinthal DA, Ocasio W (2012) The Behavioral Theory of the Firm: Assessment and Prospects. Academy of Management Annals, 6: 1-40.

Gervais S, Odean T (2001) Learning to Be Overconfident. Review of Financial Studies, 14: 1-27.

Gilovich T (1983) Biased evaluation and persistence in gambling. Journal of Personality and Social Psychology, 44: 1110-1126.

Gilovich T, Douglas C (1986) Biased evaluations of randomly determined gambling outcomes. Journal of Experimental Social Psychology, 22: 228-241.

Gino F, Pisano GP (2011) Why Leaders Don’t Learn From Success. Harvard Business Review, Apr.: 2-8.

Greve HR (2003) Organizational Learning from Performance Feedback: A Behavioral Perspective on Innovation and Change. Cambridge: Cambridge University Press.

Greve HR (1998) Performance, Aspirations, and Risky Organizational Change. Administrative Science Quarterly, 43: 58-86.

Grossman Z, Owens D (2012) An unlucky feeling: Overconfidence and noisy feedback. Journal of Economic Behavior and Organization, 84: 510-524.

Groysberg B, Sant L, Abrahams R (2008) When 'Stars' Migrate, Do They Still Perform Like Stars? MIT Sloan Management Review, Fall: 41-46.

Hale DM (2018) Chain reaction: Are turnovers about more than luck? http://www.espn.com/collegefootball/story//id/24142400/coaches-their-everlasting-quest-coach-turnovers

Holcomb TR, Holmes MR, Connelly BL (2009) Making the most of what you have: Managerial ability as a source of resource value creation. Strategic Management Journal, 30(5): 457-485.

Huber GP (1991) Organizational Learning: The Contributing Processes and the Literatures. Organization Science, 2: 88-115.

Jones EE, Harris, VA (1967) The attribution of attitudes. Journal of Experimental Social Psychology, 3: $1-24$. 
Kacsmar S (2016) 2015 Adjusted Games Lost. http://www.footballoutsiders.com/statanalysis/2016/2015-adjusted-games-lost

Kahneman D, Rosenfield AM, Gandhi L, Blaser T (2016) Noise: How to Overcome the High, Hidden Cost of Inconsistent Decision Making. Harvard Business Review, Oct.: 36-43.

Kahneman D, Tversky A (1979) Prospect theory: an analysis of decision under risk. Econometrica, XLVII: 263-291.

KC D, Staats BR, Gino F (2013) Learning from My Success and Others' Failure: Evidence from Minimally Invasive Cardiac Surgery. Management Science, 59: 2435-2449.

Khurana R (2002) The Curse of the Superstar CEO. Harvard Business Review, 80: 3-8.

Kim JW, King BG (2014) Seeing Stars: Matthew Effects and Status Bias in Major League Baseball Umpiring. Management Science, 60: 2619-2644.

Kim S, Eberhart R, Armanios D (2017) What Makes a Winner? Toward Resolving the Role of Luck and Skill in Sustained CEO Performance. https://papers.ssrn.com/sol3/papers.cfm?abstract_id=2827132

Koning RH (2003) An econometric evaluation of the effect of firing a coach on team performance. Applied Economics, 35: 555-564.

Kruger J, Dunning D (1999) Unskilled and Unaware of It: How Difficulties in Recognizing One's Own Incompetence Lead to Inflated Self-Assessments. Journal of Personality and Social Psychology, 77: 1121-1134.

Kuper S, Szymanski S (2009) Soccernomics. New York: Nation Press.

Langer EJ (1975) The illusion of control. Journal of Personality and Social Psychology, 32: 311-328.

Langville AN, Meyer CD (2012) Who's \#1? The Science of Rating and Ranking. Princeton: Princeton University Press.

Larkey P, Kadane JB, Austin R, Zamir S (1997) Skill in Games. Management Science, 43: 596-609.

Lazear E (2004) The Peter Principle: A Theory of Decline. Journal of Political Economy, 112(S1): S141S163.

Lefgren L, Platt B, Price J (2015) Sticking with What (Barely) Worked: A Test of Outcome Bias. Management Science, 61: 1121-1136.

Lerner JS, Tetlock PE (1999) Accounting for the Effects of Accountability. Psychological Bulletin, 125(2): 255-275.

Levitt B, March JG (1988) Organizational learning. Annual Review of Sociology, 14: 319-340.

Levinthal DA, March JG (1993) The Myopia of Learning. Strategic Management Journal, 14: 95-112.

Lewis M (2003) Moneyball: The Art of Winning an Unfair Game. New York: W.W. Norton.

Levy M (2016) 90 Cents of Every ‘Pay-For-Performance’ Dollar Are Paid for Luck. https://papers.ssrn.com/sol3/papers.cfm?abstract id=2837504

Lindsey J (2016) The NFL is Finally Tapping into the Power of Data. https://www.wired.com/2016/01/the-nfls-impending-data-revolution/ 
Liu C, de Rond M (2016) Good Night, and Good Luck: Perspectives on Luck in Management Scholarship. Academy of Management Annals, 10: 409-451.

Lopez M (2017) Matching to estimate the causal effects of firing an NFL coach. https://statsbylopez.com/2017/01/04/matching-to-estimate-the-causal-effects-of-firing-an-nfl$\underline{\text { coach/ }}$

Lopez M (2013) Fumble luck, Part I. https://statsbylopez.com/2013/12/18/fumble-luck-part-i/

Lopez MJ, Matthews GJ, Baumer BS (2018) How often does the best team win? A unified approach to understanding randomness in North American sport. The Annals of Applied Statistics, 12(4): 24832516 .

MacKinnon DP, Lockwood CM, Hoffman JM, West SG, Sheets V (2002) A comparison of methods to test mediation and other intervening variable effects. Psychological Methods, 7(1): 83-104.

Madsen PM, Desai V (2010) Failing to learn? The effects of failure and success on organizational learning in the global orbital launch vehicle industry. Academy of Management Journal, 53: 451476.

Maitlis S, Christianson S (2014) Sensemaking in Organizations: Taking Stock and Moving Forward. Academy of Management Annals, 8: 57-125.

Maltarich MA, Nyberg AJ, Reilly G, Abdulsalam D, Martin M (2017) Pay-for-performance, sometimes: An interdisciplinary approach to integrating economic rationality with psychological emotion to predict individual performance. Academy of Management Journal, 60(6): 2155-2174.

Manz CC, Sims HP (1981) Vicarious Learning: The Influence of Modeling on Organizational Behavior. Academy of Management Review, 6: 105-113.

March JC, March JG (1977) Almost Random Careers: The Wisconsin School Superintendency, 19401972. Administrative Science Quarterly, 22: 377-409.

March JG (2010) The Ambiguities of Experience. Ithaca: Cornell University Press.

March JG (1991) Exploration and Exploitation in Organizational Learning. Organization Science, 2: 7187.

March JG, Shapira Z (1992) Variable risk preferences and the focus of attention. Psychological Bulletin, 99: $172-183$.

March JG, Shapira Z (1987) Managerial Perspectives on Risk and Risk Taking. Management Science, 33 : 1404-1418.

Massey C, Thaler RH (2013) The Loser's Curse: Decision Making and Market Efficiency in the National Football League Draft. Management Science, 59: 1479-1495.

MasseyPeabody (2017) We've spent more than one off-season working to put "explosive" plays into our models. No way of defining them yields a predictive stat. Aug. 22. [Tweet]

Mauboussin MJ (2012) The Success Equation. Boston: Harvard Business Review Press.

McKnight M (2016) Second Nature: Why NFL coaches are so prone to clock management blunders. https://www.si.com/nfl/2016/09/05/nfl-clock-management-andy-reid-homer-smith 
McNear C (2016) The War on Analytics Comes to Cleveland: Hue Jackson's Problems With 'Moneyball' Are Likely Just Beginning. https://www.theringer.com/2016/6/8/16046924/cleveland-brownscoach-hue-jackson-vs-analytics-b55b2dda4ae4

Merton RK (1968) The Matthew Effect in Science. Science, 159: 56-63.

Milkovich G, Newman J, Gerhart B (2013) Compensation. $11^{\text {th }}$ Ed. New York: McGraw-Hill Education.

Miller DT, Ross M (1975) Self-serving biases in the attribution of causality: fact or fiction?

Psychological Bulletin, 82: 213-225.

Miller SD (2016) Cryptanalysis of the NFL Schedule. http://sites.math.rutgers.edu/ sdmiller/Cryptanalysis-of-the-NFL-Schedule.html

Moliterno TP, Beck N, Beckham CM, Meyer M (2014) Knowing Your Place: Social Performance Feedback in Good Times and Bad Times. Organization Science, 25(6): 1684-1702.

Morris B (2016) NFL Coaches Are Getting Away With Crimes Against Middle-School Math. http://fivethirtyeight.com/features/nfl-coaches-are-getting-away-with-crimes-against-middleschool-math/

Myers CG, Staats BR, Gino F (2014) “My Bad!” How Internal Attribution and Ambiguity of Responsibility Affect Learning from Failure. Harvard Business School Working Paper 14-104, April 18.

Owens MF, Roach M (2017) Decision-Making on the Hot Seat and the Short List: Evidence from College Football Fourth Down Decisions. Sept. 27. https://papers.ssrn.com/sol3/papers.cfm?abstract_id=3042666

Paine N (2014) No Team Can Beat the Draft. https://fivethirtyeight.com/features/no-team-can-beat-thedraft/

Pauley J (2018) Why Your Favorite NFL Team Might Win (or Lose) Five More Games Next Year. https://medium.com/@jaydpauley/why-your-favorite-nfl-team-might-win-or-lose-five-moregames-next-year-ff9749145d22

Perrow C (1984) Normal Accidents. New York: Basic Books.

Peta J (2013) Trading Bases. New York: Penguin.

Pluchino A, Biondo AE, Rapisarda A (2018) Talent vs Luck: The role of randomness in success and failure. https://arxiv.org/abs/1802.07068

Pomeroy K (2006) Ratings Explanation. https://kenpom.com/blog/ratings-explanation/

Pritchard D, Smith M (2004) The psychology and philosophy of luck. New Ideas in Psychology, 22: 128.

R_Thaler (2018) Note: Sanchez, Young and Bortles are above the median. This is a CRAP SHOOT. But every team thinks they have figured it out on draft day. Mar. 19. [Tweet]

R_Thaler (2015) 20 years since Romer and still no progress. Amazing failure to learn. Especially on 4th and goal. Gain 1.5 points! Sept. 12. [Tweet]

Rabin M (2002) Inference by Believers in the Law of Small Numbers. Quarterly Journal of Economics, 117: 775-816.

Romer D (2006) Do Firms Maximize? Evidence from Professional Football. Journal of Political Economy, 114: 340-365. 
Salfino M, Chairusmi J (2016) Why NFL Coaches Take No Chances. Wall Street Journal, Dec. 27.

Seifert K (2015) Across sports, NFL teams are most reluctant to take advantage of analytics. http://www.espn.com/espn/feature/story//id/12331388/the-great-analytics-rankings

Shiv B, Loewenstein G, Bechara A, Damasio H, Damasio AR (2005) Investment Behavior and the Negative Side of Emotion. Psychological Science, 16: 435-439.

Silver N (2014) Introducing NFL Elo Ratings. Accessible: https://fivethirtyeight.com/features/introducing-nfl-elo-ratings/

Simon HA (1959) Theories of Decision-Making in Economics and Behavioral Science. American Economic Review, 49(3): 253-283.

Sims HP, Gioia DA (1984) Performance Failure: Executive Response to Self-serving Bias. Business Horizons, 27: 64-71.

Smith MD (2018) Dirk Koetter: Percentages say go for it on fourth down, but if I fail I'm out of here. https://sports.yahoo.com/dirk-koetter-percentages-fourth-down-150800087.html

Stoll B (2012) Insider Trading: Sports Bookmaking and Gambling. MIT Sloan Sports Analytics Conference, Boston, MA, March 4.

Strang D, Patterson KL (2014) Asymmetries in Experiential and Vicarious Feedback: Lessons from the Hiring and Firing of Baseball Managers. Sociological Science, 1: 178-198.

Stuart HC (2017) Structural Disruption, Relational Experimentation, and Performance in Professional Hockey Teams: A Network Perspective on Member Change. Organization Science, 28: 283-300.

Taleb NN (2001) Fooled by Randomness. New York: Random House.

Thaler RH (2015) Misbehaving: The Making of Behavioral Economics. New York: W.W. Norton.

To C, Kilduff GJ, Ordoñez L, Schweitzer ME (2018) Going for it on Fourth Down: Rivalry Increases Risk Taking, Physiological Arousal, and Promotion Focus. Academy of Management Journal, 61(4): 1281-1306.

Tversky A, Kahneman D (1991) Loss Aversion in Riskless Choice: A Reference-Dependent Model. Quarterly Journal of Economics, 106: 1039-1061.

Tversky A, Kahneman D (1971) Belief in the law of small numbers. Psychological Bulletin, 76: 105-110.

Volin B (2016) Why all NFL contracts aren't fully guaranteed. Boston Globe, July 9.

Walker J, Risen JL, Gilovich T, Thaler RH (In Press) Sudden-Death Aversion: Avoiding Superior Options Because They Feel Riskier. Journal of Personality and Social Psychology.

Weintraub R (2015) Analytics gurus face plenty of challenges in the NFL. http://www.sportsonearth.com/article/142385754/nfl-analytics-denver-broncos-mitch-tanney

Winston WL (2009) Mathletics: How Gamblers, Managers and Sports Enthusiasts Use Mathematics in Baseball, Basketball and Football. Princeton: Princeton University Press.

Wolfers J (2007) Are Voters Rational? Evidence from Gubernatorial Elections. http://users.nber.org/ jwolfers/papers/Voterrationality(latest).pdf 
Figure 1a. Elo Ratings and Regular Season Wins, 1990-2015 (N=769).

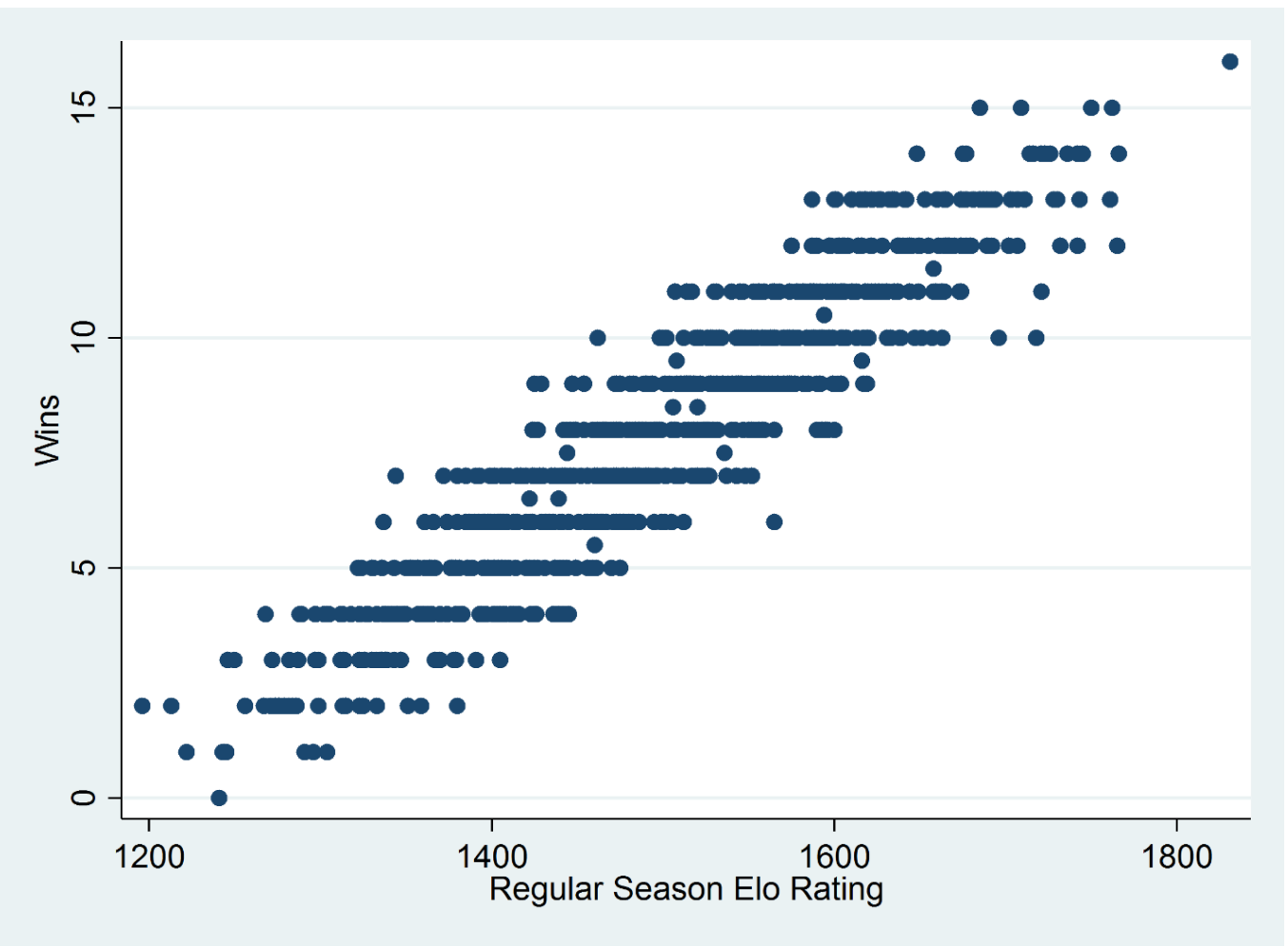

Figure 1b. Defense-adjusted Value Over Average (DVOA) Ratings and Regular Season Wins, 19902015 ( $\mathrm{N}=769)$.

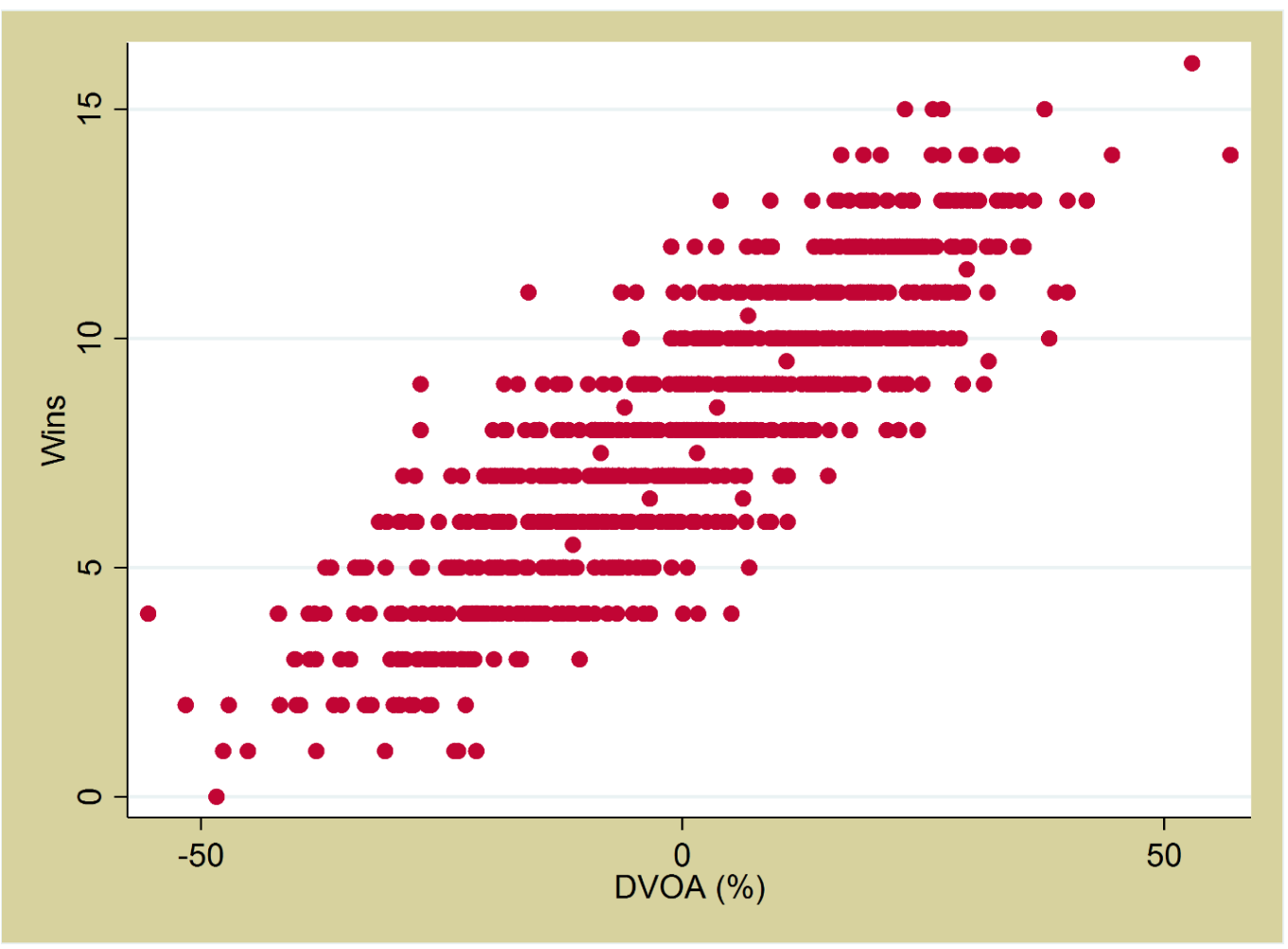


Table 1. Correlations of Luck and Performance Variables (N=769)

\begin{tabular}{|c|c|c|c|c|c|c|c|c|c|c|c|c|c|c|c|c|c|c|c|c|c|c|c|}
\hline & 1 & 2 & 3 & 4 & 5 & 6 & 7 & 8 & 9 & 10 & 11 & 12 & 13 & 14 & 15 & 16 & 17 & 18 & 19 & 20 & 21 & 22 & 23 \\
\hline 1. Wins & 1 & & & & & & & & & & & & & & & & & & & & & & \\
\hline 2. Elo Rating & 0.93 & 1 & & & & & & & & & & & & & & & & & & & & & \\
\hline 3. DVOA Rating & 0.86 & 0.91 & 1 & & & & & & & & & & & & & & & & & & & & \\
\hline 5. DVOA Luck & 0.52 & 0.30 & 0.01 & 0.66 & 1 & & & & & & & & & & & & & & & & & & \\
\hline 6. Strength of Schedule (Elo) & -0.31 & -0.14 & -0.10 & -0.49 & -0.45 & 1 & & & & & & & & & & & & & & & & & \\
\hline 7. Strength of Schedule (DVOA) & -0.22 & -0.07 & -0.02 & -0.41 & -0.40 & 0.86 & 1 & & & & & & & & & & & & & & & & \\
\hline 8. Fumble Luck & 0.06 & 0.03 & 0.00 & 0.07 & 0.12 & 0.01 & 0.07 & 7 & & & & & & & & & & & & & & & \\
\hline 9. Wins - Previous Year & 0.30 & 0.49 & 0.39 & -0.40 & -0.06 & 0.12 & 0.09 & -0.13 & 1 & & & & & & & & & & & & & & \\
\hline 10. Elo Rating - Previous Year & 0.39 & 0.60 & 0.49 & -0.45 & -0.07 & 0.10 & 0.08 & $3-0.11$ & 0.88 & 1 & & & & & & & & & & & & & \\
\hline 11. DVOA Rating - Previous Year & 0.36 & 0.57 & 0.51 & -0.44 & -0.14 & 0.15 & 0.12 & -0.10 & 0.81 & 0.91 & 1 & & & & & & & & & & & & \\
\hline 12. Strength of Schedule (Elo) - Previous Year & -0.02 & -0.03 & 0.04 & 0.02 & -0.11 & 0.15 & 0.14 & 0.05 & -0.32 & -0.16 & -0.10 & 1 & & & & & & & & & & & \\
\hline 13. Strength of Schedule (DVOA) - Previous Year & 0.01 & 0.03 & 0.09 & -0.03 & -0.13 & 0.18 & 0.20 & 0.06 & -0.23 & -0.09 & -0.02 & 0.84 & 1 & & & & & & & & & & \\
\hline 14. Fumble Luck - Previous Year & -0.07 & -0.04 & -0.05 & -0.08 & -0.06 & 0.04 & 0.01 & -0.07 & 0.07 & 0.05 & 0.01 & 0.02 & 0.08 & 1 & & & & & & & & & \\
\hline 15. Head Coach Change & -0.18 & -0.27 & -0.25 & 0.17 & 0.06 & -0.05 & -0.06 & 50.11 & -0.41 & -0.39 & -0.36 & 0.20 & 0.11 & -0.09 & 1 & & & & & & & & \\
\hline 16. Roster Holdover & 0.22 & 0.35 & 0.31 & -0.28 & -0.09 & 0.07 & 0.07 & -0.10 & 0.54 & 0.55 & 0.52 & -0.17 & -0.07 & 0.07 & -0.46 & 1 & & & & & & & \\
\hline 18. Injury Luck (2002-2015; N=447) & -0.24 & -0.19 & -0.22 & -0.18 & -0.10 & 0.21 & 0.13 & -0.02 & 0.02 & 0.04 & 0.02 & 0.00 & -0.05 & 0.04 & -0.03 & -0.01 & -0.31 & 1 & & & & & \\
\hline 19. Injury Luck - Previous Year (2003-2015; N=415) & -0.06 & -0.09 & -0.09 & 0.06 & 0.03 & 0.00 & -0.06 & 50.04 & -0.21 & -0.17 & -0.22 & 0.23 & 0.12 & -0.03 & 0.13 & -0.18 & -0.35 & 0.40 & 1 & & & & \\
\hline 20. Draft: Total Career Value Added & -0.07 & -0.16 & -0.12 & 0.22 & 0.06 & -0.05 & -0.02 & -0.05 & -0.37 & -0.34 & -0.33 & 0.17 & 0.14 & -0.10 & 0.14 & -0.26 & -0.29 & 0.02 & 0.16 & 1 & & & \\
\hline 21. Draft: Total Career Value Added (Previous Year) & -0.07 & -0.08 & -0.06 & 0.01 & -0.04 & 0.12 & 0.11 & 0.03 & -0.07 & -0.17 & -0.14 & -0.06 & -0.04 & -0.04 & -0.03 & 0.03 & -0.08 & -0.02 & 0.01 & 0.19 & 1 & & \\
\hline 22. Previous Year Coach Total Games With Team & 0.17 & 0.23 & 0.22 & -0.12 & -0.03 & -0.03 & 0.00 & -0.06 & 0.20 & 0.30 & 0.26 & 0.01 & 0.04 & -0.09 & 0.04 & 0.11 & 0.06 & -0.01 & 0.03 & 0.04 & -0.07 & 1 & \\
\hline 23. Previous Year Coach Win Percentage With Team & 0.36 & 0.53 & 0.43 & -0.35 & -0.02 & 0.03 & 0.07 & -0.08 & 30.72 & 0.81 & 0.72 & -0.18 & -0.10 & -0.04 & -0.28 & 0.34 & 0.36 & 0.03 & -0.11 & -0.26 & -0.19 & 0.39 & 1 \\
\hline
\end{tabular}


Table 2. Effects of Team Characteristics on Wins (Change from Previous Year)

\begin{tabular}{|c|c|c|c|c|c|c|c|c|c|c|c|c|c|c|}
\hline & Model 1 & Model 2 & Model 3 & Model 4 & Model 5 & Model 6 & Model 7 & Model 8 & Model 9 & Model 10 & Model 11 & Model 12 & Model 13 & Model 14 \\
\hline Total Roster Retention & \begin{tabular}{|l}
$-.211^{* * *}$ \\
$(.029)$ \\
\end{tabular} & & & & & & & & & & \begin{tabular}{|l|l}
-.014 \\
$(.265)$ \\
\end{tabular} & $\begin{array}{l}-.027 \\
(.028)\end{array}$ & \begin{tabular}{|l|l}
-.025 \\
$(.038)$ \\
\end{tabular} & $\begin{array}{l}-.015 \\
(.040)\end{array}$ \\
\hline Starter Retention & & $\begin{array}{l}-.173^{* * *} \\
(.045) \\
\end{array}$ & & & & & & & & & \begin{tabular}{|l}
$.202^{* * *}$ \\
$(.040)$ \\
\end{tabular} & \begin{tabular}{|l}
$.196 * * *$ \\
$(.042)$ \\
\end{tabular} & $\begin{array}{l}.167^{* *} \\
(.059) \\
\end{array}$ & $\begin{array}{l}.142^{*} \\
(.062) \\
\end{array}$ \\
\hline Previous Year Wins & & & $\begin{array}{l}-.643^{* * *} \\
(.034) \\
\end{array}$ & & & & & & & & \begin{tabular}{|l}
$.507^{* * *}$ \\
$(.041)$ \\
\end{tabular} & $\begin{array}{l}.519 * * * \\
(.045) \\
\end{array}$ & \begin{tabular}{|l}
$-.448 * * *$ \\
$(.056)$ \\
\end{tabular} & $\begin{array}{l}.457^{* * *} \\
(.061) \\
\end{array}$ \\
\hline Previous Year Luck (Elo) & & & & $\mid \begin{array}{l}-1.217^{* * *} \\
(.105)\end{array}$ & & & & & & & \begin{tabular}{|l|}
$-.251^{* *}$ \\
$(.094)$
\end{tabular} & & $\begin{array}{l}-. .448 * * * \\
(.345)\end{array}$ & \\
\hline $\begin{array}{l}\text { Strength of Schedule (Elo) } \\
\text { Change }\end{array}$ & & & & & \begin{tabular}{|l}
$-.061^{* * *}$ \\
$(.003)$ \\
\end{tabular} & & & & & & $\begin{array}{l}.039 * * * \\
(.003) \\
\end{array}$ & & $\begin{array}{l}-.030 * * * \\
(.005) \\
\end{array}$ & \\
\hline Previous Year Luck (DVOA) & & & & & & \begin{tabular}{|l|}
$-1.050^{* * *}$ \\
$(.072)$ \\
\end{tabular} & & & & & & \begin{tabular}{|l}
$-.342^{* * *}$ \\
$(.074)$ \\
\end{tabular} & & \begin{tabular}{|l}
$-.314^{* * *}$ \\
$(.103)$ \\
\end{tabular} \\
\hline $\begin{array}{l}\text { Strength of Schedule } \\
\text { (DVOA) Change }\end{array}$ & & & & & & & $\begin{array}{l}-.250 * * * \\
(.021)\end{array}$ & & & & & $\begin{array}{l}.144^{* * *} \\
(.019)\end{array}$ & & $\begin{array}{l}-.123^{* * *} \\
(.026) \\
\end{array}$ \\
\hline Fumble Luck Change & & & & & & & & $\begin{array}{l}.131^{* * *} \\
(.025) \\
\end{array}$ & & & \begin{tabular}{|l}
$.073 * * *$ \\
$(.019)$ \\
\end{tabular} & $\begin{array}{l}.076^{* * *} \\
(.020) \\
\end{array}$ & $\begin{array}{l}.074 * * \\
(.027) \\
\end{array}$ & \begin{tabular}{|l|}
$.080^{* *}$ \\
$(.028)$ \\
\end{tabular} \\
\hline $\begin{array}{l}\text { Value of pre-season draft } \\
\text { picks }\end{array}$ & & & & & & & & & \begin{tabular}{|l}
$.020^{* * *}$ \\
$(.003)$
\end{tabular} & & $\begin{array}{ll}.004+ \\
(.002) \\
\end{array}$ & \begin{tabular}{|l|}
.004 \\
$(.002)$ \\
\end{tabular} & $\begin{array}{l}.006 \\
(.004) \\
\end{array}$ & $\begin{array}{l}.007+ \\
(.004) \\
\end{array}$ \\
\hline $\begin{array}{l}\text { Adjusted Player Games } \\
\text { Lost Due to Injury Change }\end{array}$ & & & & & & & & & & $\begin{array}{l}-.048^{* * *} \\
(.006) \\
\end{array}$ & & & \begin{tabular}{|l|}
$-.020^{* * *}$ \\
$(.005)$ \\
\end{tabular} & $\begin{array}{l}-.025 * * * \\
(.005) \\
\end{array}$ \\
\hline Constant & $\begin{array}{l}7.574^{* * *} \\
(1.034)\end{array}$ & $\begin{array}{l}2.183^{* * *} \\
(.574) \\
\end{array}$ & $\begin{array}{l}5.219 * * * \\
(.034) \\
\end{array}$ & \begin{tabular}{|l}
.024 \\
$(.118)$ \\
\end{tabular} & \begin{tabular}{|l}
.025 \\
$(.107)$
\end{tabular} & \begin{tabular}{|l}
.020 \\
$(.113)$ \\
\end{tabular} & \begin{tabular}{|l}
.024 \\
$(.117)$
\end{tabular} & \begin{tabular}{|l}
.020 \\
$(.125)$
\end{tabular} & \begin{tabular}{|l|}
$-3.290^{* * *}$ \\
$(.534)$ \\
\end{tabular} & $\begin{array}{l}.130 \\
(.168) \\
\end{array}$ & $\begin{array}{l}1.421 \\
(.969) \\
\end{array}$ & $\begin{array}{l}2.051^{*} \\
(1.010) \\
\end{array}$ & \begin{tabular}{|l}
1.631 \\
$(1.413)$ \\
\end{tabular} & $\begin{array}{l}1.551 \\
(1.452) \\
\end{array}$ \\
\hline R2 & .066 & .019 & .318 & .150 & .290 & .219 & .155 & .034 & .050 & .119 & .481 & .434 & .472 & .439 \\
\hline $\mathbf{N}$ & 769 & 769 & 769 & 769 & 769 & 769 & 769 & 769 & 769 & 416 & 769 & 769 & 416 & 416 \\
\hline
\end{tabular}

$+\mathrm{p}<.10 ; * \mathrm{p}<.05 ; * * \mathrm{p}<.01 ; * * * \mathrm{p}<.001$ (two-tailed tests). Note: Standard Errors are in parentheses. 
Table 3. Logistic Regression of Luck-Based Factors and Coach Characteristics on Likelihood of Coach Retention (Univariate)

\begin{tabular}{|c|c|c|c|c|c|c|c|c|c|c|}
\hline & Model 1 & Model 2 & Model 3 & Model 4 & Model 5 & Model 6 & Model 7 & Model 8 & Model 9 & Model 10 \\
\hline Previous Year Wins & $\begin{array}{l}1.394^{* * *} \\
(.049)\end{array}$ & & & & & & & & & \\
\hline Previous Year Luck (Elo) & & $\begin{array}{l}1.640^{* * *} \\
(.137)\end{array}$ & & & & & & & & \\
\hline $\begin{array}{l}\text { Previous Year Strength of } \\
\text { Schedule (Elo) }\end{array}$ & & & $\begin{array}{l}.981 * * * \\
(.004)\end{array}$ & & & & & & & \\
\hline Previous Year Luck (DVOA) & & & & $\begin{array}{l}1.462 * * * \\
(.090)\end{array}$ & & & & & & \\
\hline $\begin{array}{l}\text { Previous Year Strength of } \\
\text { Schedule (DVOA) }\end{array}$ & & & & & $\begin{array}{l}.942^{* *} \\
(.020)\end{array}$ & & & & & \\
\hline Previous Year Fumble Luck & & & & & & $\begin{array}{l}1.037 \\
(.025)\end{array}$ & & & & \\
\hline $\begin{array}{l}\text { Previous Year Player Games } \\
\text { Lost due to Injuries }\end{array}$ & & & & & & & $\begin{array}{l}.987^{* *} \\
(.005)\end{array}$ & & & \\
\hline Coach Total Games with Team & & & & & & & & $\begin{array}{l}.997^{*} \\
(.001)\end{array}$ & & \\
\hline Coach Total Win \% with Team & & & & & & & & & $\begin{array}{l}40.107^{* * *} \\
(24.240)\end{array}$ & \\
\hline $\begin{array}{l}\text { Previous Year Value of Draft } \\
\text { Picks }\end{array}$ & & & & & & & & & & $\begin{array}{l}1.003 \\
(.002)\end{array}$ \\
\hline Constant & $\begin{array}{l}.319 * * * \\
(.079)\end{array}$ & $\begin{array}{l}3.880 * * * \\
(.362)\end{array}$ & $\begin{array}{l}.000^{* * *} \\
(.000)\end{array}$ & $\begin{array}{l}3.933 * * * \\
(.371)\end{array}$ & $\begin{array}{l}3.624^{* * *} \\
(.320)\end{array}$ & $\begin{array}{l}3.599 * * * \\
(.310)\end{array}$ & $\begin{array}{l}7.471 * * * \\
(2.221)\end{array}$ & $\begin{array}{l}4.480 * * * \\
(.594)\end{array}$ & $\begin{array}{l}.587+ \\
(.175)\end{array}$ & $\begin{array}{l}2.002+ \\
(.740)\end{array}$ \\
\hline $\mathbf{R 2}$ & .140 & .047 & .033 & .052 & .011 & .003 & .016 & .007 & .048 & .003 \\
\hline $\mathbf{N}$ & 769 & 769 & 769 & 769 & 769 & 769 & 416 & 769 & 769 & 769 \\
\hline
\end{tabular}

$+\mathrm{p}<.10 ; * \mathrm{p}<.05 ; * * \mathrm{p}<.01 ; * * * \mathrm{p}<.001$ (two-tailed tests). Note: Standard Errors are in parentheses. 
Table 3 (ctd). Logistic Regression of Luck-Based Factors and Coach Characteristics on Likelihood of Coach Retention (Multivariate)

\begin{tabular}{|c|c|c|c|c|c|c|c|}
\hline & Model 11 & Model 12 & Model 13 & Model 14 & Model 15 & Model 16 & Model 17 \\
\hline \multicolumn{8}{|l|}{ Previous Year Wins } \\
\hline Previous Year Luck (Elo) & $\begin{array}{l}1.464 * * * \\
(.135)\end{array}$ & & & $\begin{array}{l}1.478^{* * *} \\
(.147)\end{array}$ & & $\begin{array}{l}1.393^{*} \\
(.201)\end{array}$ & \\
\hline $\begin{array}{l}\text { Previous Year Strength of } \\
\text { Schedule (Elo) }\end{array}$ & $\begin{array}{l}.988 * * \\
(.004)\end{array}$ & & & $\begin{array}{l}.992+ \\
(.005)\end{array}$ & & $\begin{array}{l}.992 \\
(.007)\end{array}$ & \\
\hline Previous Year Luck (DVOA) & & $\begin{array}{l}1.435^{* * *} \\
(.095)\end{array}$ & & & $\begin{array}{l}1.324^{* * *} \\
(.092)\end{array}$ & & $\begin{array}{l}1.274^{*} \\
(.129)\end{array}$ \\
\hline $\begin{array}{l}\text { Previous Year Strength of } \\
\text { Schedule (DVOA) }\end{array}$ & & $\begin{array}{l}.987 \\
(.022)\end{array}$ & & & $\begin{array}{l}.990 \\
(.023)\end{array}$ & & $\begin{array}{l}.992 \\
(.032)\end{array}$ \\
\hline Previous Year Fumble Luck & $\begin{array}{l}1.029 \\
(.026)\end{array}$ & $\begin{array}{l}1.017 \\
(.026)\end{array}$ & & $\begin{array}{l}1.024 \\
(.027)\end{array}$ & $\begin{array}{l}1.104 \\
(.027)\end{array}$ & $\begin{array}{l}1.076+ \\
(.042)\end{array}$ & $\begin{array}{l}1.065 \\
(.042)\end{array}$ \\
\hline $\begin{array}{l}\text { Previous Year Player Games } \\
\text { Lost due to Injuries }\end{array}$ & & & & & & $\begin{array}{l}.995 \\
(.006)\end{array}$ & $\begin{array}{l}.993 \\
(.005)\end{array}$ \\
\hline Coach Total Games with Team & & & $\begin{array}{l}.991 * * * \\
(.002)\end{array}$ & $\begin{array}{l}.992 * * * \\
(.002)\end{array}$ & $\begin{array}{l}.992 * * * \\
(.002)\end{array}$ & $\begin{array}{l}.991 * * * \\
(.003)\end{array}$ & $\begin{array}{l}.991 * * * \\
(.003)\end{array}$ \\
\hline Coach Total Win \% with Team & & & $\begin{array}{l}289.716 * * * \\
(213.235)\end{array}$ & $\begin{array}{l}235.755^{* * *} \\
(179.619)\end{array}$ & $\begin{array}{l}147.400^{* * *} \\
(111.944)\end{array}$ & $\begin{array}{l}953.701^{* * *} \\
(1143.295)\end{array}$ & $\begin{array}{l}653.316 * * * \\
(788.063)\end{array}$ \\
\hline $\begin{array}{l}\text { Previous Year Value of Draft } \\
\text { Picks }\end{array}$ & & & $\begin{array}{l}1.007^{* *} \\
(.002)\end{array}$ & $\begin{array}{l}1.004+ \\
(.002)\end{array}$ & $\begin{array}{l}1.006^{*} \\
(.002)\end{array}$ & $\begin{array}{l}1.004 \\
(.004)\end{array}$ & $\begin{array}{l}1.006 \\
(.004)\end{array}$ \\
\hline Constant & $\begin{array}{l}.000^{* *} \\
(.000)\end{array}$ & $\begin{array}{l}3.933^{* * *} \\
(.371)\end{array}$ & $\begin{array}{l}.131^{* * *} \\
(.072)\end{array}$ & $\begin{array}{l}46415.44 \\
(325491.200)\end{array}$ & $\begin{array}{l}.236^{*} \\
(.135)\end{array}$ & $\begin{array}{l}35871.130 \\
(358872.700)\end{array}$ & $\begin{array}{l}.201+ \\
(.188)\end{array}$ \\
\hline $\mathbf{R 2}$ & .058 & .053 & .092 & .134 & .120 & .159 & .150 \\
\hline $\mathbf{N}$ & 769 & 769 & 769 & 769 & 769 & 416 & 416 \\
\hline
\end{tabular}

$+\mathrm{p}<.10 ; * \mathrm{p}<.05 ; * * \mathrm{p}<.01 ; * * * \mathrm{p}<.001$ (two-tailed tests). Note: Standard Errors are in parentheses. 
Table 4a. Regression of Team Characteristics and Luck-Based Factors on Player Retention (Total Roster)

\begin{tabular}{|c|c|c|c|c|c|c|c|c|c|c|c|c|}
\hline & Model 1 & Model 2 & Model 3 & Model 4 & Model 5 & Model 6 & Model 7 & Model 8 & Model 9 & Model 10 & Model 11 & Model 12 \\
\hline Previous Year Wins & $\begin{array}{l}.690 * * * \\
(.043) \\
\end{array}$ & & & & & & & & & & & \\
\hline Previous Year Luck (Elo) & & \begin{tabular}{|l}
$.587 * * *$ \\
$(.137)$ \\
\end{tabular} & & & & & & & $\begin{array}{l}.270+ \\
(.152) \\
\end{array}$ & $\begin{array}{l}-.042 \\
(.211) \\
\end{array}$ & & \\
\hline $\begin{array}{l}\text { Previous Year Strength of } \\
\text { Schedule (Elo) }\end{array}$ & & & $\begin{array}{l}-.031 * * * \\
(.006)\end{array}$ & & & & & & $\begin{array}{l}-.021^{* *} \\
(.007)\end{array}$ & $\begin{array}{l}-.021^{*} \\
(.010)\end{array}$ & & \\
\hline $\begin{array}{l}\text { Previous Year Luck } \\
\text { (DVOA) }\end{array}$ & & & & \begin{tabular}{|l}
$.601 * * *$ \\
$(.096)$ \\
\end{tabular} & & & & & & & \begin{tabular}{|l}
$.507 * * *$ \\
$(.105)$ \\
\end{tabular} & $\begin{array}{l}.467^{* *} \\
(.147) \\
\end{array}$ \\
\hline $\begin{array}{l}\text { Previous Year Strength of } \\
\text { Schedule (DVOA) }\end{array}$ & & & & & $\begin{array}{l}-.091 * \\
(.036)\end{array}$ & & & & & & \begin{tabular}{|l}
.001 \\
$(.038)$ \\
\end{tabular} & $\begin{array}{l}.037 \\
(.051)\end{array}$ \\
\hline $\begin{array}{l}\text { Previous Year Fumble } \\
\text { Luck }\end{array}$ & & & & & & $\begin{array}{l}.085^{*} \\
(.042) \\
\end{array}$ & & & \begin{tabular}{|l|}
.062 \\
$(.042)$ \\
\end{tabular} & \begin{tabular}{|l|}
.066 \\
$(.062)$ \\
\end{tabular} & \begin{tabular}{|l}
.040 \\
$(.043)$ \\
\end{tabular} & \begin{tabular}{|l|}
.035 \\
$(.062)$ \\
\end{tabular} \\
\hline Total Draft Picks Value & & & & & & & \begin{tabular}{|l}
$.023 * * *$ \\
$(.004)$
\end{tabular} & & $\begin{array}{l}.020^{* * *} \\
(.004)\end{array}$ & $\begin{array}{l}.026 * * * \\
(.006)\end{array}$ & $\begin{array}{l}.020^{* * *} \\
(.004)\end{array}$ & $\begin{array}{l}.025^{* * *} \\
(.006)\end{array}$ \\
\hline $\begin{array}{l}\text { Previous Year Player } \\
\text { Games Lost due to Injuries }\end{array}$ & & & & & & & & $\begin{array}{l}-.033^{* * *} \\
(.009)\end{array}$ & & $\begin{array}{l}-.022^{*} \\
(.009)\end{array}$ & & $\begin{array}{l}-.026^{* *} \\
(.009)\end{array}$ \\
\hline Constant & $\begin{array}{l}30.239 * * * \\
(.376) \\
\end{array}$ & $\begin{array}{l}35.817^{* * * *} \\
(.153)\end{array}$ & $\begin{array}{l}82.683^{* * *} \\
(9.614)\end{array}$ & $\begin{array}{l}35.819^{* * *} \\
(.151)\end{array}$ & \begin{tabular}{|l}
$35.811^{* * *}$ \\
$(.155)$
\end{tabular} & $\begin{array}{l}35.800 * * * \\
(.151)\end{array}$ & $\begin{array}{l}39.677^{* * *} \\
(.630)\end{array}$ & $\begin{array}{l}37.957^{* * *} \\
(.506)\end{array}$ & $\begin{array}{l}70.055^{* * *} \\
(10.658) \\
\end{array}$ & $\begin{array}{l}72.910 * * * \\
(15.229)\end{array}$ & $\begin{array}{l}39.168^{* * *} \\
(.648)\end{array}$ & $\begin{array}{l}41.630^{* * *} \\
(1.205)\end{array}$ \\
\hline $\mathbf{R 2}$ & .247 & .024 & .030 & .048 & .008 & .005 & .048 & .032 & .076 & .098 & .084 & .110 \\
\hline $\mathbf{N}$ & 769 & 769 & 769 & 769 & 769 & 769 & 769 & 416 & 769 & 416 & 769 & 416 \\
\hline
\end{tabular}

$+\mathrm{p}<.10 ; * \mathrm{p}<.05 ; * * \mathrm{p}<.01 ; * * * \mathrm{p}<.001$ (two-tailed tests). Note: Standard Errors are in parentheses. 
Table 4b. Regression of Team Characteristics and Luck-Based Factors on Player Retention (Players Starting 9 or More Games in Previous and Current Year)

\begin{tabular}{|c|c|c|c|c|c|c|c|c|c|c|c|c|}
\hline & Model 1 & Model 2 & Model 3 & Model 4 & Model 5 & Model 6 & Model 7 & Model 8 & Model 9 & Model 10 & Model 11 & Model 12 \\
\hline Previous Year Wins & $\begin{array}{l}.436^{* * *} \\
(.029) \\
\end{array}$ & & & & & & & & & & & \\
\hline $\begin{array}{l}\text { Previous Year Luck } \\
\text { (Elo) }\end{array}$ & & $\begin{array}{l}.302^{* * *} \\
(.090)\end{array}$ & & & & & & & $\begin{array}{l}.021 \\
(.100)\end{array}$ & $\begin{array}{l}-.137 \\
(.128)\end{array}$ & & \\
\hline $\begin{array}{l}\text { Previous Year Strength } \\
\text { of Schedule (Elo) }\end{array}$ & & & $\begin{array}{l}-.026^{* * *} \\
(.004)\end{array}$ & & & & & & $\begin{array}{l}-.023^{* * *} \\
(.005) \\
\end{array}$ & $\begin{array}{l}-.013^{*} \\
(.006)\end{array}$ & & \\
\hline $\begin{array}{l}\text { Previous Year Luck } \\
\text { (DVOA) }\end{array}$ & & & & $\begin{array}{l}.251^{* * *} \\
(.064)\end{array}$ & & & & & & & $\begin{array}{l}.141^{*} \\
(.070)\end{array}$ & $\begin{array}{l}.049 \\
(.090)\end{array}$ \\
\hline $\begin{array}{l}\text { Previous Year Strength } \\
\text { of Schedule (DVOA) }\end{array}$ & & & & & $\begin{array}{l}-.089 * * * \\
(.023)\end{array}$ & & & & & & $\begin{array}{l}-.061 * \\
(.025)\end{array}$ & $\begin{array}{l}-.010 \\
(.031)\end{array}$ \\
\hline $\begin{array}{l}\text { Previous Year Fumble } \\
\text { Luck }\end{array}$ & & & & & & $\begin{array}{l}.049+ \\
(.028) \\
\end{array}$ & & & $\begin{array}{l}.037 \\
(.028) \\
\end{array}$ & $\begin{array}{l}-.005 \\
(.037) \\
\end{array}$ & $\begin{array}{l}.034 \\
(.028) \\
\end{array}$ & $\begin{array}{l}-.011 \\
(.003) \\
\end{array}$ \\
\hline Total Draft Picks Value & & & & & & & $\begin{array}{l}-.009 * * * \\
(.002)\end{array}$ & & $\begin{array}{l}-.008^{* * *} \\
(.002)\end{array}$ & $\begin{array}{l}-.018^{* * *} \\
(.004)\end{array}$ & $\begin{array}{l}-.009 * * * \\
(.002)\end{array}$ & $\begin{array}{l}-.018^{* * *} \\
(.004)\end{array}$ \\
\hline $\begin{array}{l}\text { Previous Year Player } \\
\text { Games Lost due to } \\
\text { Injuries }\end{array}$ & & & & & & & & \begin{tabular}{|l}
$-.042 * * *$ \\
$(.005)$ \\
\end{tabular} & & \begin{tabular}{|l}
$-.036 * * *$ \\
$(.005)$ \\
\end{tabular} & & $\begin{array}{l}-.037 * * * \\
(.005) \\
\end{array}$ \\
\hline Constant & \begin{tabular}{|l}
$8.966^{* * *}$ \\
$(.249)$ \\
\end{tabular} & \begin{tabular}{|l|}
$12.485^{* * *}$ \\
$(.101)$
\end{tabular} & \begin{tabular}{|l|}
$51.057^{* * *}$ \\
$(6.237)$
\end{tabular} & \begin{tabular}{|l}
$12.486^{* * *}$ \\
$(.101)$
\end{tabular} & \begin{tabular}{|l|}
$12.478^{* * *}$ \\
$(.101)$
\end{tabular} & \begin{tabular}{|l|}
$12.535^{* * *}$ \\
$(.099)$
\end{tabular} & $\begin{array}{l}14.034^{* * *} \\
(.420)\end{array}$ & \begin{tabular}{|l}
$14.124 * * *$ \\
$(.306)$
\end{tabular} & $\begin{array}{l}48.784 \\
(7.020)\end{array}$ & $\begin{array}{l}35.921 * * * \\
(9.197)\end{array}$ & \begin{tabular}{|l|}
$13.932 * * *$ \\
$(.433)$
\end{tabular} & $\begin{array}{l}16.811^{* * *} \\
(.626)\end{array}$ \\
\hline $\mathbf{R 2}$ & .230 & .015 & .048 & .020 & .018 & .004 & .017 & .123 & .064 & .186 & .045 & .179 \\
\hline $\mathbf{N}$ & 769 & 769 & 769 & 769 & 769 & 769 & 769 & 416 & 769 & 416 & 769 & 416 \\
\hline
\end{tabular}

$+\mathrm{p}<.10 ; * \mathrm{p}<.05 ; * * \mathrm{p}<.01 ; * * * \mathrm{p}<.001$ (two-tailed tests). Note: Standard Errors are in parentheses. 
Figure 2a. Theoretical Mediation Model of Luck, Personnel Retention and Future Performance

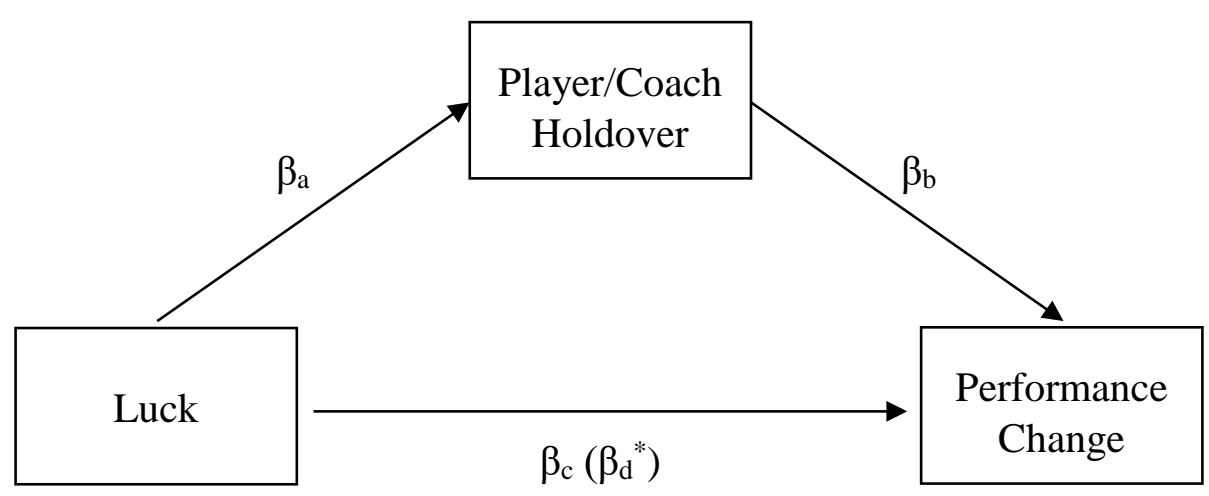

Figure 2b. Mediation Model of Elo Luck, Annual Roster Retention and Following Year Win Change

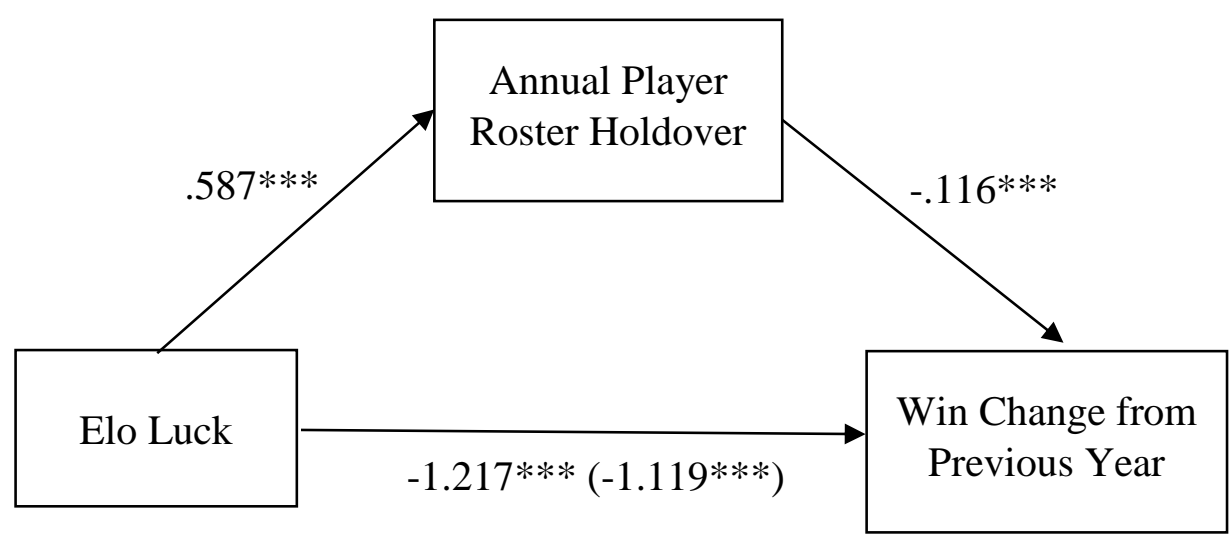

